Article

\title{
Dioxygen Activation with Molybdenum Complexes Bearing Amide-Functionalized Iminophenolate Ligands
}

\author{
Niklas Zwettler, Madeleine A. Ehweiner, Jörg A. Schachner, Antoine Dupé, Ferdinand Belaj \\ and Nadia C. Mösch-Zanetti *(D) \\ Institute of Chemistry, Inorganic Chemistry, University of Graz, Schubertstrasse 1, 8010 Graz, Austria; \\ niklas.zwettler@uni-graz.at (N.Z.); madeleine.ehweiner@uni-graz.at (M.A.E.); \\ joerg.schachner@uni-graz.at (J.A.S.); antoine.dupe@uni-graz.at (A.D.); ferdinand.belaj@uni-graz.at (F.B.) \\ * Correspondence: nadia.moesch@uni-graz.at; Tel.: +43-316-380-5286
}

Academic Editor: Antonella Dalla Cort

Received: 17 April 2019; Accepted: 9 May 2019; Published: 10 May 2019

\begin{abstract}
Two novel iminophenolate ligands with amidopropyl side chains (HL2 and HL3) on the imine functionality have been synthesized in order to prepare dioxidomolybdenum(VI) complexes of the general structure $\left[\mathrm{MoO}_{2} \mathbf{L}_{2}\right]$ featuring pendant internal hydrogen bond donors. For reasons of comparison, a previously published complex featuring $n$-butyl side chains (L1) was included in the investigation. Three complexes (1-3) obtained using these ligands (HL1-HL3) were able to activate dioxygen in an in situ approach: The intermediate molybdenum(IV) species $\left[\mathrm{MoO}\left(\mathrm{PMe}_{3}\right) \mathbf{L}_{2}\right]$ is first generated by treatment with an excess of $\mathrm{PMe}_{3}$. Subsequent reaction with dioxygen leads to oxido peroxido complexes of the structure $\left[\mathrm{MoO}\left(\mathrm{O}_{2}\right) \mathbf{L}_{2}\right]$. For the complex employing the ligand with the $n$-butyl side chain, the isolation of the oxidomolybdenum(IV) phosphino complex $\left[\mathrm{MoO}\left(\mathrm{PMe}_{3}\right)(\mathbf{L 1})_{2}\right]$ (4) was successful, whereas the respective Mo(IV) species employing the ligands with the amidopropyl side chains were found to be not stable enough to be isolated. The three oxido peroxido complexes of the structure $\left[\mathrm{MoO}\left(\mathrm{O}_{2}\right) \mathbf{L}_{2}\right]$ (9-11) were systematically compared to assess the influence of internal hydrogen bonds on the geometry as well as the catalytic activity in aerobic oxidation. All complexes were characterized by spectroscopic means. Furthermore, molecular structures were determined by single-crystal X-ray diffraction analyses of HL3, 1-3, 9-11 together with three polynuclear products $\left\{\left[\mathrm{MoO}(\mathbf{L} 2)_{2}\right]_{2}(\mu-\mathrm{O})\right\}(7),\left\{[\mathrm{MoO}(\mathbf{L} 2)]_{4}(\mu-\mathrm{O})_{6}\right\}(8)$ and $\left[\mathrm{C}_{9} \mathrm{H}_{13} \mathrm{~N}_{2} \mathrm{O}_{4}\left[\mathrm{Mo}_{8} \mathrm{O}_{26}\right] \cdot 6 \mathrm{OPMe}_{3}(\mathbf{1 2})\right.$ which were obtained during the synthesis of reduced complexes of the type $\left[\mathrm{MoO}\left(\mathrm{PMe}_{3}\right) \mathrm{L}_{2}\right](4-6)$.
\end{abstract}

Keywords: molybdenum; iminophenolate ligands; dioxygen activation; peroxido complexes

\section{Introduction}

Molybdenum is an earth-abundant transition metal with crucial biological relevance for most organisms including humans [1-3]. The molybdenum(VI) dioxido motif, which is widespread in oxygen atom transfer (OAT) enzymes [1,4,5], sparked the intensive investigation of mononuclear dioxidomolybdenum(VI) complexes over the past decades, both in biomimetic chemistry as well as in oxygenation catalysis [2,6-13]. A major drawback in virtually all reported catalytic systems is, however, the necessity of a terminal oxidant [13-21]. Thus, the possibility to use environmentally benign and cheap dioxygen (or even air) would be highly desirable [22]. Several transition metals, including molybdenum, are known to activate dioxygen [23-32]. In our group, molybdenum(IV) complexes based on $\beta$-ketiminate and iminophenolate ligand systems were investigated regarding their usability in dioxygen activation [33-36]. As a result, we were able to demonstrate the catalytic aerobic oxidation of phosphanes and determine the influence of steric and electronic properties of the 
ligands. In this context, we reported the unusual electronic properties of the first imido supported molybdenum peroxido complex [35]. A common disadvantage of the investigated systems is, however, the rather high stability of molybdenum(VI) oxido and peroxido complexes, which is why we are currently investigating intra- and intermolecular additives to render these moieties more reactive. Very recently, we were able to increase the reactivity of a terminal molybdenum oxido group by the addition of a strong Lewis acid, leading to a reduction of the $\mathrm{Mo}=\mathrm{O}$ bond with hydrosilanes [37].

Inspired by biomimetic modeling approaches focusing on the importance of the second coordination sphere, e.g., hydrogen bonding [23,24,38-43], we started to investigate the influence of internal hydrogen bond donors on dioxygen activation. Previous results demonstrated a beneficial effect of such side-arm functionalized iminophenolate ligands on catalytic activity and selectivity [16]. First attempts to introduce an amide side-arm into an iminophenolate ligand system unexpectedly resulted in stepwise $\mathrm{C}-\mathrm{C}$ and $\mathrm{C}-\mathrm{N}$ coupling upon coordination at the electron poor dioxidomolybdenum(VI) center (Figure 1) [44]. This unusual coupling behavior is presumably caused by the two electron withdrawing moieties adjacent to the methylene carbon. We thus reasoned that an elongation of the side chain by one methylene group should allow for the isolation of the desired complexes (Figure 1).

2<smiles></smiles>

2<smiles>[R][NH2+]C(=O)CC/N=C/c1cc([R])cc([R])c1O</smiles>

this work: $\mathrm{C}_{2}$-bridge results in desired complexes with intramolecular $\mathrm{H}$-bond donors

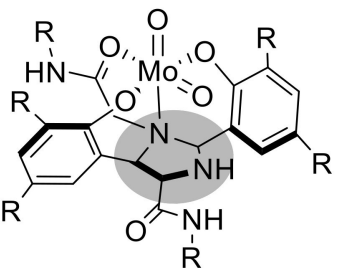

$\mathrm{R}=\mathrm{H}, t \mathrm{Bu}$

$\mathrm{R}^{\prime}=t \mathrm{Bu}, \mathrm{Ph}$

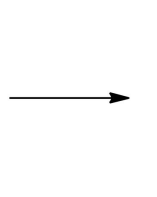

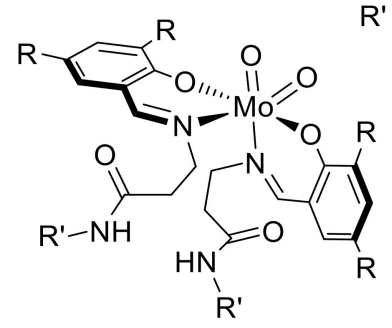

Figure 1. Iminophenolate ligands with amide functionalities featuring a $C_{1}$ and $C_{2}$ bridge, respectively, and their behavior upon coordination to $\left[\mathrm{MoO}_{2}\right]^{2+}$.

Herein, we report on the synthesis and coordination chemistry of novel iminophenolate ligands with amidopropyl functionalities, which were successfully coordinated to dioxidomolybdenum centers to form mononuclear complexes bearing pendant amide functionalities as hydrogen bond donors. The synthesis of such mononuclear complexes has not always been achieved since basic conditions during the synthetic procedure often result in deprotonation of the $\mathrm{N}-\mathrm{H}$ leading to unidentified polymeric compounds [45]. The resulting compounds were investigated with regard to the reduction of the metal center and subsequent dioxygen activation. For comparison, a previously reported dioxidomolybdenum complex featuring $n$-butyl side chains was also investigated [16]. All three dioxidomolybdenum complexes were able to activate dioxygen in an in situ approach via molybdenum(IV) species. The formed oxido peroxido complexes were fully characterized including single-crystal X-ray diffraction analysis. The dioxido complexes were furthermore found to be active precatalysts in aerobic oxidation.

\section{Results and Discussion}

\subsection{Ligand Synthesis}

Ligand HL1 featuring $n$-butyl side chains was synthesized according to a previously published procedure (Scheme 1) [46]. The novel amide-functionalized ligands HL2 and HL3 are accessible starting with commercially available $\beta$-alanine in a four-step procedure as shown in Scheme 1 . In the 
first step, the amino group is protected with a carboxybenzyl $(\mathrm{Cbz})$ group according to published procedures [47]. In the second step, the carboxylic acid moiety is chlorinated using ethyl chloroformate, and subsequent reaction with a primary amine yields the tert-butyl and phenyl amide derivatives, respectively. Deprotection with $\mathrm{Pd} / \mathrm{C}, \mathrm{H}_{2}(\mathrm{R}=t \mathrm{Bu})$ or $\mathrm{HBr}(33 \%$ in acetic acid; $\mathrm{R}=\mathrm{Ph})$ gives the desired free aminoamides, which were subsequently condensed with 3,5-di-tert-butyl-2-hydroxybenzaldehyde to yield the desired Schiff base ligands HL2 ( $\mathrm{R}=t \mathrm{Bu}, 56 \%$ overall yield) and HL3 ( $\mathrm{R}=\mathrm{Ph}, 48 \%$ overall yield).

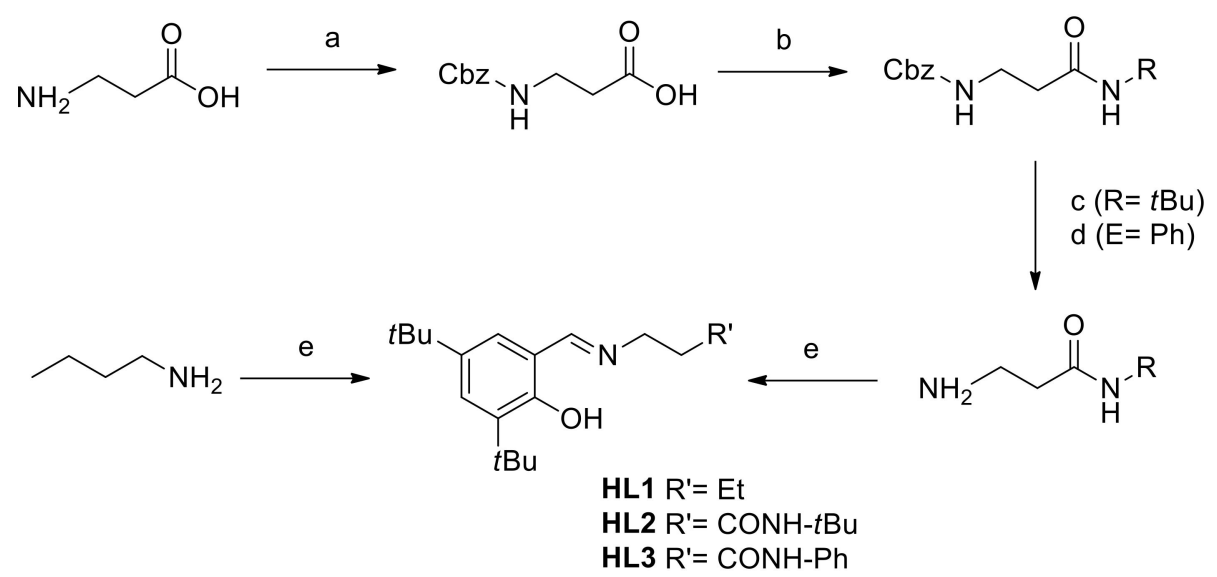

Scheme 1. Synthesis of HL1-HL3; (a) benzyl chloroformate (1 equiv), $\mathrm{NaOH} 1 \mathrm{M}, 0{ }^{\circ} \mathrm{C}$ to $25^{\circ} \mathrm{C}, 16 \mathrm{~h}$; (b) i. ethyl chloroformate (1 equiv), $\mathrm{Et}_{3} \mathrm{~N}$ (1 equiv), toluene, $-10^{\circ} \mathrm{C}, 15 \mathrm{~min}$; ii. $\mathrm{R}^{-\mathrm{NH}_{2}}$ (1 equiv in $10 \mathrm{~mL}$ $\mathrm{CHCl}_{3}$ ), toluene, $-10^{\circ} \mathrm{C}$ to $110^{\circ} \mathrm{C}, 1 \mathrm{~h}$; (c) $\mathrm{Pd} / \mathrm{C}(15 \mathrm{w} \%), \mathrm{H}_{2}(5 \mathrm{~atm}), \mathrm{MeOH}, 25^{\circ} \mathrm{C}, 16 \mathrm{~h}$; (d) i. $\mathrm{HBr}(33 \%$ in $\mathrm{AcOH}, 20 \mathrm{~mL}$ ), $25^{\circ} \mathrm{C}, 16 \mathrm{~h}$; ii. $\mathrm{NaOH} 2 \mathrm{M}$; (e) 3,5-di-tert-butyl-2-hydroxybenzaldehyde (1 equiv), $\mathrm{MeOH}, 60^{\circ} \mathrm{C}, 16 \mathrm{~h}$.

Analytical data for the previously reported ligand HL1 match those in literature [46]. All three ligands HL1-HL3 were characterized by ${ }^{1} \mathrm{H}$ - and ${ }^{13} \mathrm{C}-\mathrm{NMR}$ and IR spectroscopy as well as EI-MS; for HL3, the molecular structure was determined via single-crystal X-ray diffraction analysis. Similar to the related amidoethyl (C1) analogues [44], HL2 and HL3 (amidopropyl, C2) feature a significant difference in the shift of the amide $\mathrm{NH}$ proton depending on the $\mathrm{R}^{\prime}$ substituent (4.86 ppm in HL2 and 6.89 ppm in HL3, tert-butyl amide vs. phenyl amide, $\mathrm{C}_{6} \mathrm{D}_{6}$ ).

\subsection{Synthesis of Dioxidomolybdenum(VI) Complexes}

For the synthesis of molybdenum(VI) complexes of the type $\left[\mathrm{MoO}_{2} \mathbf{L}_{2}\right]$, synthetic procedures using $\left[\mathrm{MoO}_{2}(\mathrm{acac})_{2}\right]$ [48], $\left[\mathrm{MoO}_{2} \mathrm{Cl}_{2}\right]$ or $\left[\mathrm{MoO}_{2} \mathrm{Br}_{2}(\mathrm{DMSO})_{2}\right]$ [49] as metal source were investigated. Alternative to the literature [16], complex $\left[\mathrm{MoO}_{2}(\mathbf{L 1})_{2}\right](\mathbf{1})$ was synthesized via a reaction of two equiv of $\mathbf{H L 1}$ with the metal precursor $\left[\mathrm{MoO}_{2} \mathrm{Br}_{2}(\mathrm{DMSO})_{2}\right]$ in the presence of excess $\mathrm{NEt}_{3}$ in good yield. Complex $\left[\mathrm{MoO}_{2}(\mathbf{L} 2)_{2}\right]$ (2) was synthesized following a similar procedure using $\left[\mathrm{MoO}_{2} \mathrm{Cl}_{2}\right]$ and two equiv HL2 in the presence of excess $\mathrm{NEt}_{3}$. The compound was also accessible in good yield by reacting two equiv of HL2 with $\left[\mathrm{MoO}_{2}(\mathrm{acac})_{2}\right]$. Complex $\left[\mathrm{MoO}_{2}(\mathrm{~L} 3)_{2}\right]$ (3) was synthesized in good yield via reaction of $\left[\mathrm{MoO}_{2} \mathrm{Cl}_{2}\right]$ with two equiv of $\mathbf{H L} 3$. Synthesis attempts starting from $\left[\mathrm{MoO}_{2}(\mathrm{acac})_{2}\right]$ resulted in the formation of the monosubstituted complex $\left[\mathrm{MoO}_{2}(\mathrm{acac})(\mathrm{L} 3)\right]\left(3^{\mathrm{acac}}\right)$ instead. This statement is supported by ${ }^{1} \mathrm{H}-\mathrm{NMR}$ spectroscopy featuring resonances for one acetylacetonate and one iminophenolate ligand, as well as single-crystal X-ray diffraction analysis (vide infra). The formation of such a monosubstituted complex was previously observed with a phenyl-imine based ligand [36]. All complex syntheses are summarized in Scheme 2. 


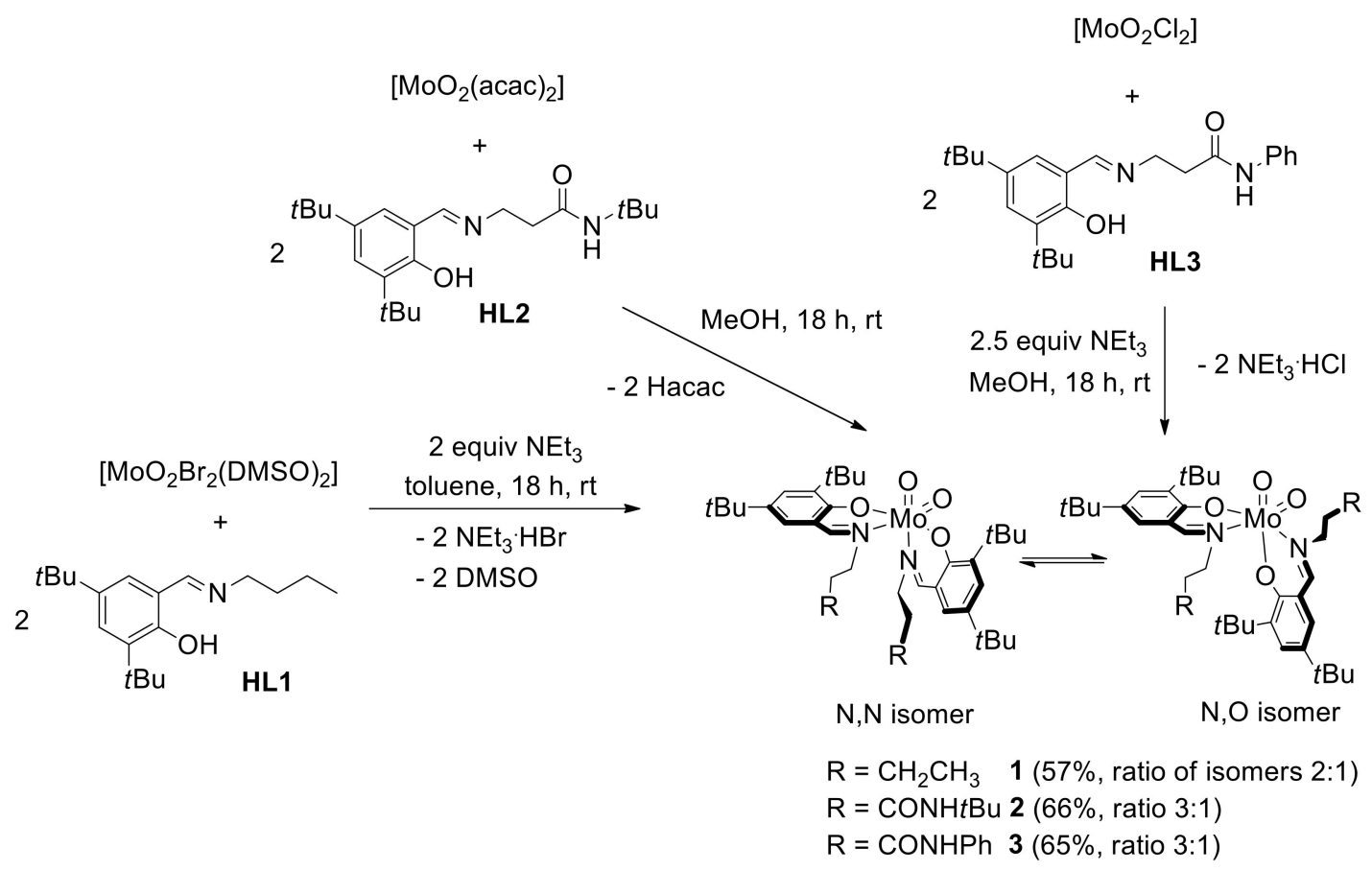

Scheme 2. Synthesis of complexes 1-3.

Complexes 1-3 are in a dynamic equilibrium between a symmetric ( $N, N$ with respect to the oxido trans positions) and an asymmetric isomer $(\mathrm{N}, \mathrm{O})$ in solution, with approximate isomeric ratios of 2:1 $\left(1, \mathrm{C}_{6} \mathrm{D}_{6}\right)$ and 3:1 (2 and 3, $\left.\mathrm{C}_{6} \mathrm{D}_{6}\right)$. The $N, N$ isomer is electronically favored while large groups at $N$ lead to the $\mathrm{O}, \mathrm{O}$ isomer as observed in a system with a iminophenolate ligand with a tert-butyl group at nitrogen [34]. However, in solid state, complexes 1-3 exhibit exclusively the $N, N$ arrangement (vide infra), which is in good agreement with previous observations [16,36]. Complexes 2 and 3 feature the desired dangling arms with intramolecular amide hydrogen bond donors, confirmed by the broad singlet resonances in the ${ }^{1} \mathrm{H}-\mathrm{NMR}$ spectra. In addition, ${ }^{1} \mathrm{H}-\mathrm{NMR}$ spectroscopy reveals a pronounced downfield shift of the resonances for the amide proton in comparison to the free ligand (e.g., 6.12 vs. $4.86 \mathrm{ppm}, 2$ vs. HL2, $\mathrm{C}_{6} \mathrm{D}_{6}$ ), presumably indicating hydrogen bonding to an oxido ligand in solution [50-53]. The bidentate coordination mode of $\mathbf{L} \mathbf{2}$ and $\mathbf{L 3}$ is in agreement with previous observations for iminophenolate complexes with or without additional donor atoms, whereas related aminophenolate ligands coordinate in a facial tridentate fashion due to their higher coordinative flexibility $[15,16,18]$.

As expected, complexes 1-3 are sensitive to moisture. Whereas complex $\mathbf{1}$ is well soluble in most common laboratory solvents including aliphatic hydrocarbons, complex $\mathbf{2}$ is well soluble in chlorinated hydrocarbons, benzene and toluene, but shows poor solubility in $\mathrm{MeCN}$ and $\mathrm{MeOH}$. Complex 3 is well soluble in $\mathrm{CH}_{2} \mathrm{Cl}_{2}$, but exhibits only limited solubility in other standard laboratory solvents. The composition as well as the (mononuclear) structure of complexes 1-3 was confirmed by spectroscopic measurements $\left({ }^{1} \mathrm{H}\right.$ - and $\left.{ }^{13} \mathrm{C}-\mathrm{NMR}, \mathrm{IR}\right)$, mass spectrometry, elemental analysis and single-crystal $\mathrm{X}$-ray diffraction analysis (vide infra).

\subsection{Reduction of Complexes 1-3 and Activation of Dioxygen}

Reaction of $\left[\mathrm{MoO}_{2}(\mathbf{L 1})_{2}\right]$ (1) with five equiv of $\mathrm{PMe}_{3}$ resulted in the formation of the phosphane coordinated $\mathrm{Mo}(\mathrm{IV})$ oxido compound $\left[\mathrm{MoO}\left(\mathrm{PMe}_{3}\right)(\mathbf{L 1})_{2}\right]$ (4) in good yield (Scheme 3). Similar to the ${ }^{1} \mathrm{H}-\mathrm{NMR}$ resonances for $\mathbf{1}$, also compound $\mathbf{4}$ features signals for two species, reflected by two distinct sets of resonances for two ligands each. Additionally, two distinct resonances for coordinated $\mathrm{PMe}_{3}$ are observed in the ${ }^{31} \mathrm{P}\left\{{ }^{1} \mathrm{H}\right\}$-NMR spectrum. The isomeric ratio for compound 4 is approximately $4: 1$, with the major isomer probably adopting the $O, O$ conformation, which is in accordance with 
previous reports [36]. Addition of five equiv of $\mathrm{PMe}_{3}$ to complexes 2 or 3 led to a similar mixture of isomers of compounds $\left[\mathrm{MoO}\left(\mathrm{PMe}_{3}\right)(\mathbf{L} 2)_{2}\right](5)$ and $\left[\mathrm{MoO}\left(\mathrm{PMe}_{3}\right)(\mathbf{L} 3)_{2}\right](6) .{ }^{1} \mathrm{H}-$ and ${ }^{31} \mathrm{P}\left\{{ }^{1} \mathrm{H}\right\}-\mathrm{NMR}$ spectroscopy revealed for $\mathbf{5}$ also two and for $\mathbf{6}$ at least three isomers in solution. Although these data point to the actual formation of $\mathbf{5}$ and $\mathbf{6}$, we were unable to isolate them in pure form. Any purification attempts led to the formation of several new, presumably polynuclear species together with free ligand. Nevertheless, during such attempts with $\mathbf{5}$, two types of single crystals were obtained revealing the formation of a $\mu$-oxido bridged molybdenum(V) dimer, $\left\{\left[\mathrm{MoO}(\mathbf{L} 2)_{2}\right]_{2}(\mu-\mathrm{O})\right\}(7)$, which is similar to previous observations [36], as well as a tetranuclear $\mu$-oxido bridged molybdenum(VI) cluster, $\left\{[\mathrm{MoO}(\mathbf{L} 2)]_{4}(\mu-\mathrm{O})_{6}\right\}(\mathbf{8})$, as depicted in Figure 2 . We attribute the increased instability and the resulting decomposition to the additional acidic functionalities in the ligand side chains. The tetranuclear structure of $\mathbf{8}$ has not been described before in molybdenum coordination chemistry; only a tungsten derivative is known [54]. In contrast, the structural motifs of $\mathbf{7}$ and $\mathbf{1 2}$ (vide infra) are quite common [36,55-57].
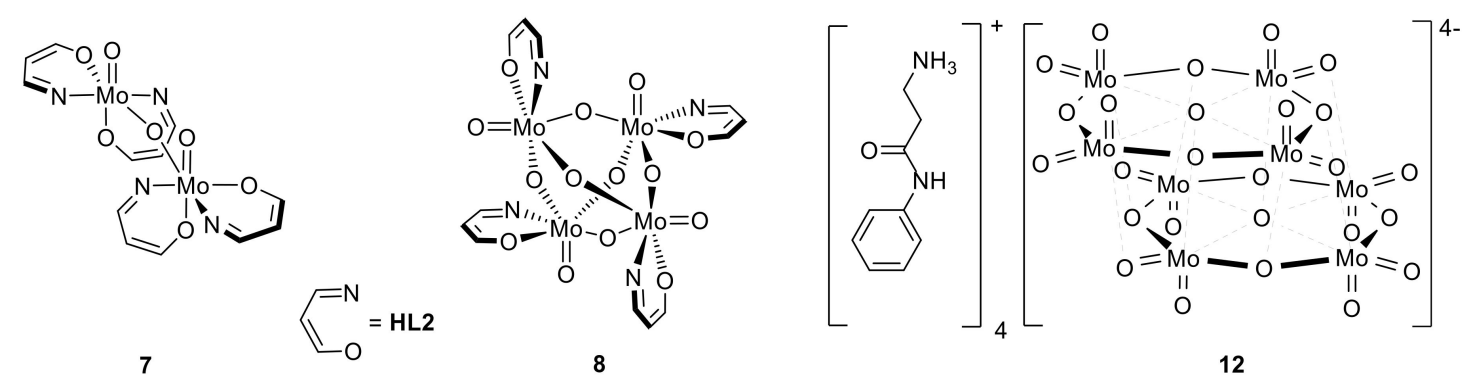

Figure 2. Polynuclear compounds $\mathbf{7}$ and $\mathbf{8}$ forming during reduction of $\mathbf{2}$ with $\mathrm{PMe}_{3}$, and $\mathbf{1 2}$ forming during reduction of 3 with $\mathrm{PMe}_{3}$ under $\mathrm{O}_{2}$ atmosphere.

Complex 4 is very well soluble in most common organic solvents including aliphatic hydrocarbons. The compound is highly sensitive to moisture and air and tends to slowly decompose in solution. The composition of $\mathbf{4}$ was additionally confirmed via FT-IR spectroscopy and elemental analysis. Compound 5 was characterized in situ via ${ }^{1} \mathrm{H}-,{ }^{13} \mathrm{C}$ - and ${ }^{31} \mathrm{P}\left\{{ }^{1} \mathrm{H}\right\}-\mathrm{NMR}$ spectroscopy under inert conditions. Compounds $\mathbf{7}$ and $\mathbf{8}$ were only obtained in small quantities of single crystals and thus were only characterized via single-crystal X-ray diffraction analysis.

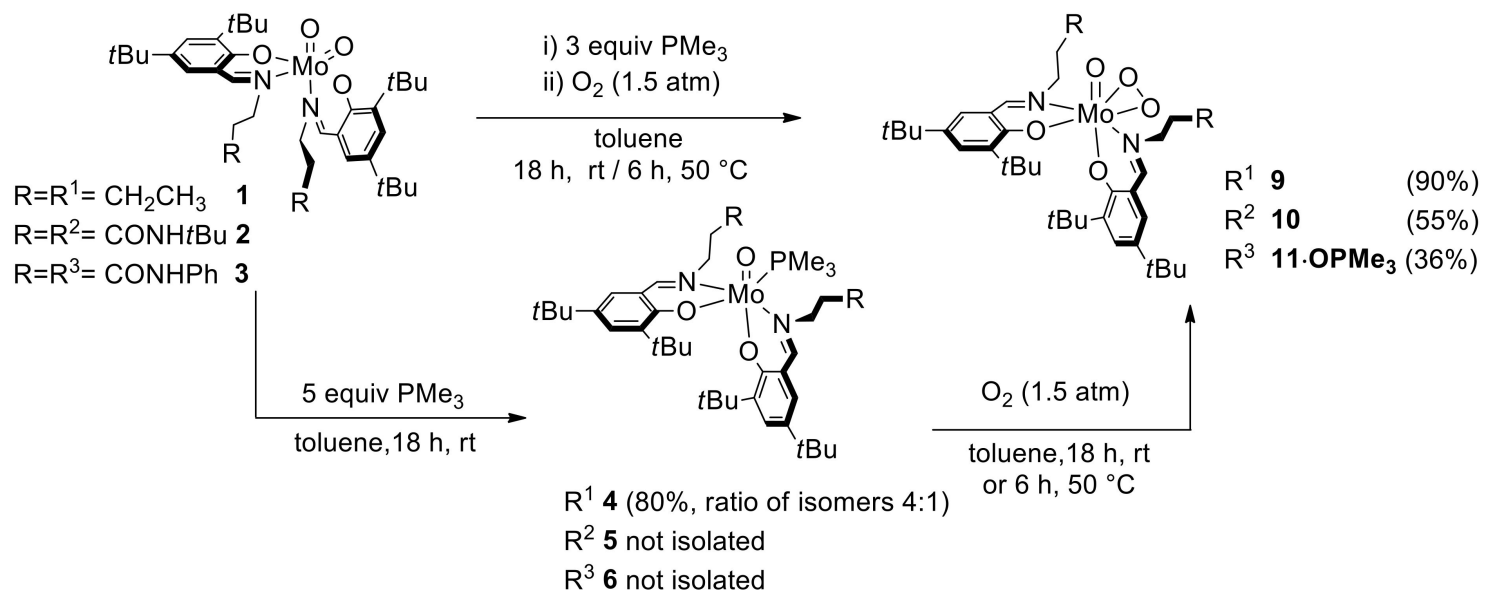

Scheme 3. Oxygen atom transfer (OAT) reactivity of complexes 1-3 and activation of $\mathrm{O}_{2}$ to form oxido peroxido compounds $\mathbf{9 - 1 1}$. For clarity, only the major isomer is depicted for all complexes.

The phosphane coordinated complex 4 cleanly reacts with dioxygen, which is indicated by a quick color change from red-brown to orange-red, to form the desired oxido peroxido compound $\left[\mathrm{MoO}\left(\mathrm{O}_{2}\right)(\mathbf{L} \mathbf{1})_{2}\right](\mathbf{9})$ in excellent yield. Alternatively, $\mathbf{9}$ is also accessible in a one-pot reaction via the 
addition of three equiv of $\mathrm{PMe}_{3}$ to a toluene solution of 1 and subsequent stirring under $\mathrm{O}_{2}$ atmosphere for $18 \mathrm{~h}$, which is similar to previous reports [34,36]. Such a direct formation of the oxido peroxido species from the corresponding molybdenum dioxido complex was also investigated for complexes 2 and 3 (Scheme 3). For the synthesis of $\left[\mathrm{MoO}\left(\mathrm{O}_{2}\right)(\mathbf{L 2})_{2}\right](\mathbf{1 0})$, the same protocol as described above could be applied. A noteworthy difference, however, was the work-up procedure, since removal of residual $\mathrm{OPMe}_{3}$ via an extraction protocol using benzene or alkanes resulted in the isolation of a 1:1 mixture of $\mathbf{1 0}$ with $\mathrm{OPMe}_{3}$. This mixture was subsequently identified via single-crystal X-ray diffraction as $\mathbf{1 0} \cdot \mathrm{OPMe}_{3}$ in which $\mathrm{OPMe}_{3}$ is hydrogen-bonded to the amide (vide infra). Nonetheless, recrystallization of the crude reaction product from the coordinating solvent $\mathrm{MeCN}$ yielded microcrystalline 10 in good yield as well as single crystals of this $\mathrm{OPMe}_{3}$-free compound. For the formation of $\left[\mathrm{MoO}\left(\mathrm{O}_{2}\right)(\mathbf{L} 3)_{2}\right](\mathbf{1 1})$, an analogous reaction at room temperature was examined. However, only a slow reaction progress as well as side product formation (presumably a dimeric compound) was observed. An increase of the reaction temperature to $50{ }^{\circ} \mathrm{C}$ led to the formation of the desired compound and additionally allowed for a shorter reaction $(6 \mathrm{~h})$. Similar to $\mathbf{1 0}$, after work-up, a 1:1 mixture of $\mathbf{1 1}$ and $\mathrm{OPMe}_{3}$ was observed. In contrast to $\mathbf{1 0}$, however, recrystallization from $\mathrm{MeCN}$ did not remove the $\mathrm{OPMe}_{3}$, presumably because of the more acidic amide $\mathrm{N}-\mathrm{H}$ groups and thus stronger hydrogen bonds. Compound 11 was thus isolated as 11. $\mathrm{OPMe}_{3}$ in fair yield. Slow evaporation of a concentrated MeCN solution of $\mathbf{1 1} \cdot \mathrm{OPMe}_{3}$ led to single crystals of two distinct adducts of $\mathbf{1 1}\left(\mathbf{1 1} \cdot \mathrm{OPMe}_{3}\right.$ and 11.2OPMe $\mathrm{OP}_{3}$ asell as a small quantity of crystals, which could be identified as a hydrolysis/decomposition product of the formula $\left[\mathrm{C}_{9} \mathrm{H}_{13} \mathrm{~N}_{2} \mathrm{O}_{4}\left[\mathrm{Mo}_{8} \mathrm{O}_{26}\right] \cdot 6 \mathrm{OPMe}_{3}(\mathbf{1 2}\right.$, Figure 2). The sensitivity of 11 towards hydrolysis is noteworthy, since it is in contrast to previously investigated molybdenum(VI) oxido peroxido complexes [35,36]. Complex 9 exists as a mixture of two isomers in solution, with an isomeric ratio of $>10: 1$, as determined by ${ }^{1} \mathrm{H}-\mathrm{NMR}$ spectroscopy; for complexes $\mathbf{1 0}$ and $\mathbf{1 1}$, only a single isomer is observed. All three complexes were found to adopt the $O, O$ isomer in solid state via single-crystal $X$-ray diffraction analysis and, based on spectroscopic evidence, the isomeric conformation is the same in solution, which is in agreement with previous observations [14,33,34,36]. In compound 10, the ${ }^{1} \mathrm{H}-\mathrm{NMR}$ resonances for the amide protons exhibit a slight upfield shift in comparison to $\left[\mathrm{MoO}_{2}(\mathbf{L 2})_{2}\right]$ (2), which is in contrast to the solid state structures (vide infra), where no hydrogen bond is observed in 2 but a weak interaction to the peroxido group in 10. This finding suggests generally flexible and weak interactions in our complexes. The amide resonances in $\mathbf{1 1}$ are shifted downfield in comparison to 3, which is probably caused by hydrogen bonding to OPMe 3 . Complexes 9-11 are well soluble in most common laboratory solvents and moderately soluble in alkanes. Whereas complexes $\mathbf{9}$ and $\mathbf{1 0}$ are stable to air and only slightly sensitive to moisture, complex $\mathbf{1 1}$ tends to decompose within days upon exposure to moisture.

\subsection{Molecular Structures}

Molecular structures of the ligand HL3, molybdenum(VI) dioxido complexes 1-3, as well as molybdenum(VI) oxido peroxido complexes 9, 10, 10. $\mathrm{PMM}_{3}, \mathbf{1 1} \cdot \mathrm{OPMe}_{3}, \mathbf{1 1} \cdot 2 \mathrm{OPMe}_{3}$ and the side products 7, 8 and 12 were determined by single-crystal X-ray diffraction analysis. Molecular views of 1-3 are given in Figure 3, molecular views of 9, 10 and $\mathbf{1 1}\left(\mathrm{OPMe}_{3}\right)$ in Figure 4 and the intermolecular hydrogen bonding in the phosphane oxide adducts of $10 \cdot \mathrm{OPMe}_{3}$ and 11.2OPMe $\mathrm{Pin}_{3}$ Figure 5. The molecular views of the ligand HL3, the monosubstituted complex $3^{\text {acac }}$ as well as the polynuclear compounds 7, 8 and 12 are depicted in Figures S2-S6 in the Supplementary Materials. Selected bond lengths and angles for complexes 1-3 are provided in Table 1 and for complexes 9, 10 and 11.2OPMe 3 in Table 2. Full crystallographic details such as structure refinement as well as experimental details are provided within the Supplementary Materials. 


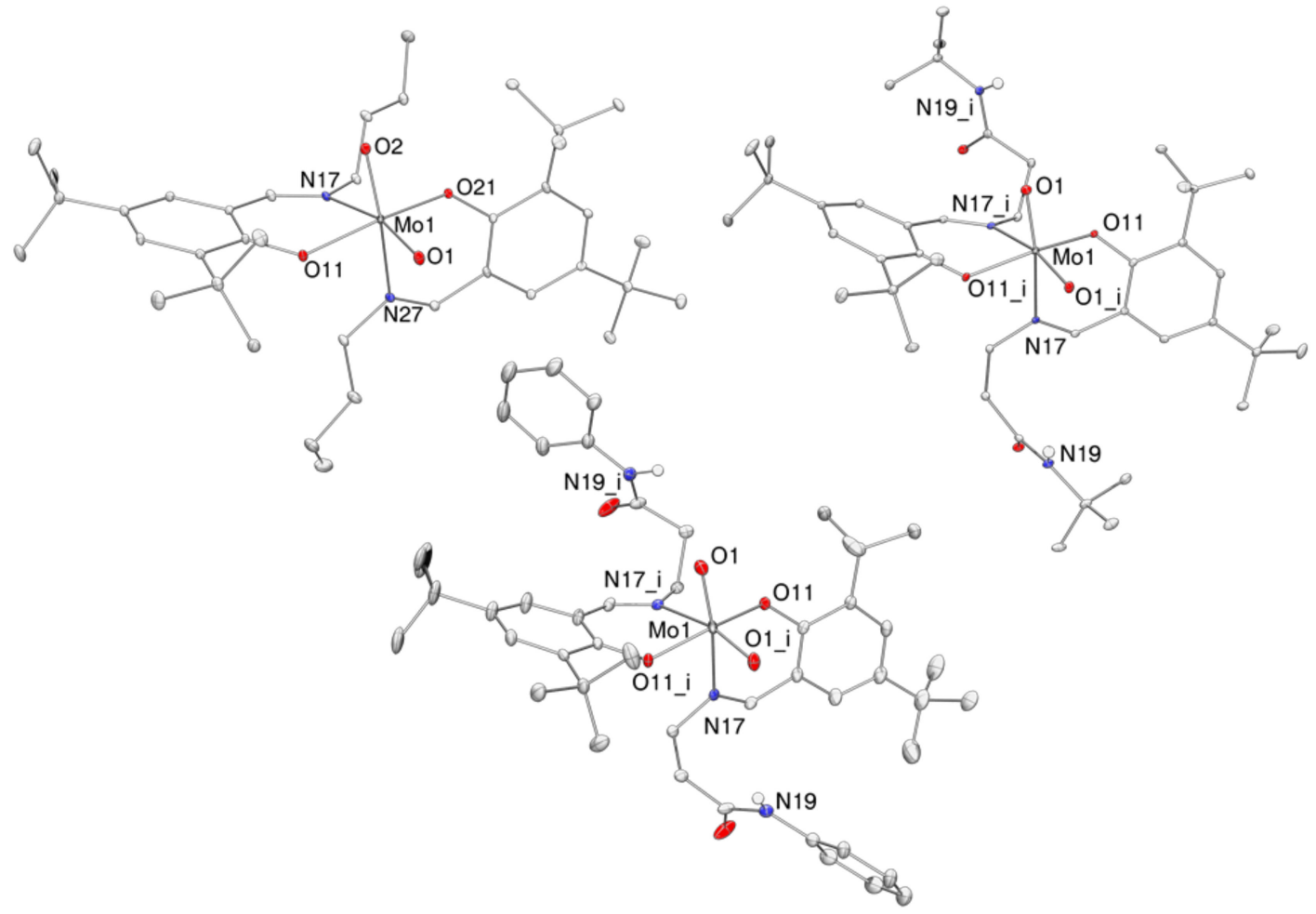

Figure 3. Molecular views (50\% probability level) of the dioxidomolybdenum(VI) complexes $\left[\mathrm{MoO}_{2}(\mathbf{L 1})_{2}\right]^{15}$ (1, top left), [ $\left.\mathrm{MoO}_{2}(\mathbf{L} 2)_{2}\right]$ (2, top right) and $\left[\mathrm{MoO}_{2}(\mathbf{L} 3)_{2}\right]$ (3, bottom). H atoms, except amide protons, as well as solvent molecules are omitted for clarity reasons.

In complexes 1-3, the molybdenum atoms are coordinated in a distorted octahedral fashion by two bidentate ligands and two oxido ligands, with the iminophenolate ligands adopting the $N, N$ isomeric form with respect to the oxido trans positions. Hydrogen bonding from the pendant amide functionalities to the oxido ligands is not observed. The bond lengths to all ligands are very similar in complexes 1-3; only the Mo-N bonds are slightly shorter in complex 3. The $\mathrm{Mo}=\mathrm{O}$ bond lengths are within expected ranges (Table 1) [58].

Table 1. Selected bond lengths $(\AA)$ and angles $\left(^{\circ}\right)$ for the dioxidomolybdenum(VI) complexes 1-3.

\begin{tabular}{cccc}
\hline & $\mathbf{1}$ & $\mathbf{2}$ & $\mathbf{3}$ \\
\hline Mo1-O1 & $1.705(3)$ & $1.7078(10)$ & $1.708(3)$ \\
Mo1-O2 & $1.712(3)$ & - & - \\
Mo1-O11 & $1.952(3)$ & $1.9571(10)$ & $1.950(2)$ \\
Mo1-O21 & $1.955(3)$ & - & - \\
Mo1-N17 & $2.351(2)$ & $2.3548(12)$ & $2.333(3)$ \\
Mo1-N27 & $2.341(4)$ & - & - \\
O1-Mo1-O2 & $106.80(16)$ & $107.62(7)$ & $108.0(2)$ \\
O11-Mo1-O21 & $160.48(11)$ & $157.63(6)$ & $159.49(16)$ \\
N17-Mo1-N27 & $73.30(12)$ & $73.42(6)$ & $74.78(16)$ \\
\hline
\end{tabular}



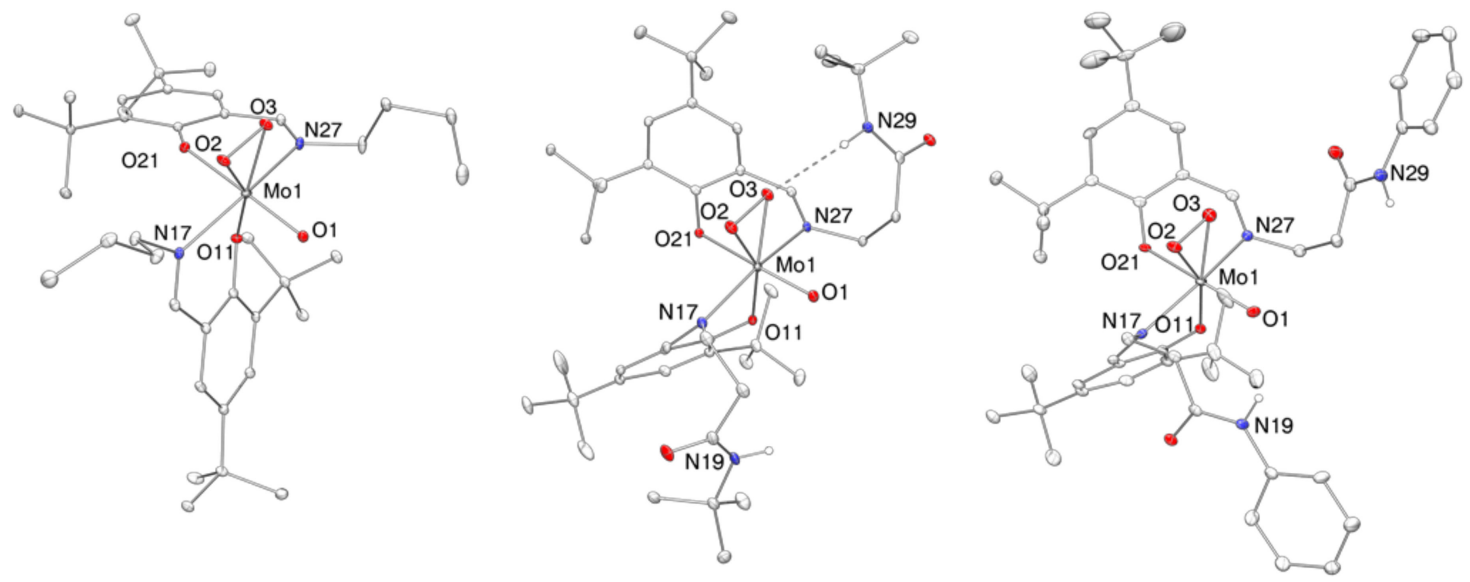

Figure 4. Molecular views (50\% probability level) of the oxido peroxido molybdenum(VI) complexes $\left[\mathrm{MoO}\left(\mathrm{O}_{2}\right)(\mathbf{L 1})_{2}\right](\mathbf{9}$, left $),\left[\mathrm{MoO}\left(\mathrm{O}_{2}\right)(\mathbf{L} 2)_{2}\right]\left(\mathbf{1 0}\right.$, middle) and $\left[\mathrm{MoO}\left(\mathrm{O}_{2}\right)(\mathbf{L} 3)_{2}\right](\mathbf{1 1}$, right). H atoms, except amide protons, as well as solvent molecules and $\mathrm{OPMe}_{3}$ (in 11) are omitted for clarity reasons.

In compounds 9-11, the molybdenum centers are coordinated by two bidentate iminophenolate ligands, an oxido ligand and $\mathrm{a} \eta^{2}$ side-on coordinated peroxido ligand in a distorted octahedral fashion. All three compounds adopt the $O, O$ isomeric form in solid state, with the phenolate oxygen atoms trans to the oxido and peroxido ligand, respectively. The change of the isomeric form, with respect to the parent complexes 1-3, is reflected by the N17-Mo1-N27 and O11-Mo-O21 bond angles. Additionally, the Mo-N bonds are shortened by approx. $0.15 \AA$ on average, whereas the Mo-O (phenolate) bonds are slightly elongated, caused by the trans influence of the oxido (and peroxido) ligands. The bonds to the bidentate ligands as well as the $\mathrm{Mo}=\mathrm{O}$ bonds are of similar length in all oxido peroxido complexes in the observed modifications. Comparison of the $\mathrm{Mo}-(\mathrm{O}-\mathrm{O})$ bond lengths of all three complexes shows a rather small influence of the ligand. The bond lengths in $\mathbf{1 0}$ follow the expected trend in comparison to 9 , namely a shortening of the Mo- $(\mathrm{O}-\mathrm{O})$ bonds as well as a slight elongation of the $(\mathrm{O}-\mathrm{O})$ bond due to the electron richer tert-butyl system. The shorter $(\mathrm{O}-\mathrm{O})$ bond in complex $\mathbf{1 1}$ could then be explained by the rather electron withdrawing character of the phenyl system.

Table 2. Selected bond lengths $(\AA)$ and angles $\left(^{\circ}\right)$ for the oxido peroxido molybdenum(VI) complexes 9 , 10 and $\mathbf{1 1} \cdot 2 \mathrm{OPMe}_{3}$

\begin{tabular}{cccc}
\hline & $\mathbf{9}$ & $\mathbf{1 0}$ & $\mathbf{1 1 \cdot 2 O P M \mathbf { P } _ { 3 }}$ \\
\hline Mo1-O1 & $1.6817(18)$ & $1.6959(13)$ & $1.698(3)$ \\
Mo1-O2 & $1.9573(19)$ & $1.9398(13)$ & $1.961(4)$ \\
Mo1-O3 & $1.9469(16)$ & $1.9651(14)$ & $1.945(3)$ \\
Mo1-O11 & $2.0353(10)$ & $2.0256(13)$ & $2.014(3)$ \\
Mo1-O21 & $2.0113(10)$ & $2.0283(12)$ & $2.036(3)$ \\
Mo1-N17 & $2.1670(14)$ & $2.1542(15)$ & $2.167(4)$ \\
Mo1-N27 & $2.2053(14)$ & $2.1818(15)$ & $2.189(4)$ \\
O2-O3 & $1.431(3)$ & $1.4426(18)$ & $1.406(4)$ \\
O1-Mo1-O2 & $101.97(9)$ & $100.50(6)$ & $99.89(15)$ \\
O1-Mo1-O3 & $99.60(8)$ & $98.18(6)$ & $98.13(14)$ \\
O2-Mo1-O3 & $43.01(7)$ & $43.35(5)$ & $42.21(13)$ \\
O11-Mo1-O21 & $80.51(4)$ & $81.56(5)$ & $82.21(12)$ \\
N17-Mo1-N27 & $159.62(5)$ & $161.89(6)$ & $161.32(13)$ \\
\hline
\end{tabular}



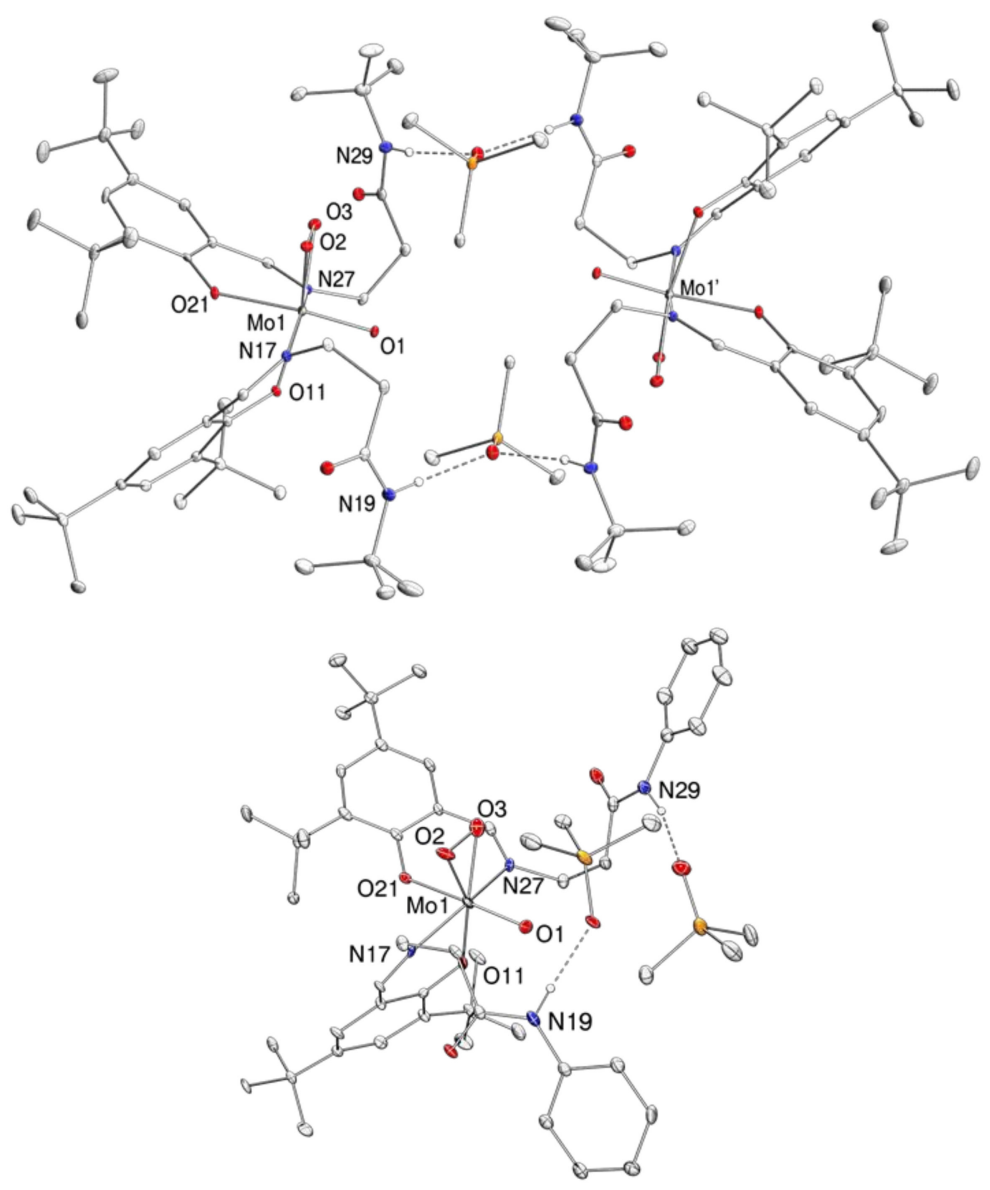

Figure 5. Molecular views (50\% probability level) of the hydrogen bonds in the oxido peroxido complex adducts $\left\{\left[\mathrm{MoO}\left(\mathrm{O}_{2}\right)(\mathbf{L} 2)_{2}\right]_{2}\left(\mathrm{OPMe}_{3}\right)_{2}\right\}\left(\mathbf{1 0} \cdot \mathrm{OPMe}_{3}\right.$, top $)$ and $\left\{\left[\mathrm{MoO}\left(\mathrm{O}_{2}\right)(\mathbf{L} 3)_{2}\right]\left(\mathrm{OPMe}_{3}\right)_{2}\right\}\left(\mathbf{1 1} \cdot 2 \mathrm{OPMe}_{3}\right.$, bottom). $\mathrm{H}$ atoms, except amide protons, as well as solvent molecules are omitted for clarity reasons.

The amido hydrogen atoms of compounds $\mathbf{1 0}$ and $\mathbf{1 1}$ are in principle involved in hydrogen bonding. Since the latter was only isolable with additional $\mathrm{OPMe}_{3}$ molecules, hydrogen bonding to the oxygen atom of the phosphine occurred exclusively (Figure 5, bottom). In compound 10, a weak intramolecular hydrogen bond from the amide $\mathrm{H}$ to one $\mathrm{O}$ atom of the peroxido moiety is formed

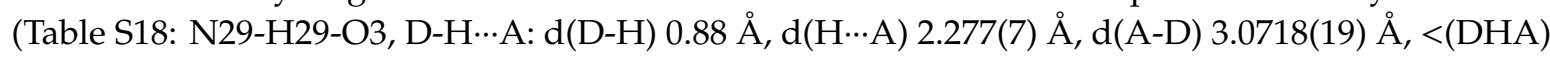
$\left.150.1(12)^{\circ}\right)$. However, comparison of the $\mathrm{O}-\mathrm{O}$ bond length in $\mathbf{1 0}$ to that of $\mathbf{9}$ (without hydrogen bond) reveals little influence (Table 2). While the pending substituent is able to rotate into the right position or distance to the peroxido ligand, the flexibility seems to be too high for effective hydrogen bonding in the desired fashion. However, hydrogen bonding might facilitate reactivity by bringing the substrate in close proximity to the peroxido group.

\subsection{Catalysis}

The catalytic aerobic oxidation of trimethyl phosphane as a widespread model reaction using complexes 1-3, according to Equation (1), was investigated. Used conditions were $1 \mathrm{~mol} \%$ catalyst under $1 \mathrm{~atm}$ of dry $\mathrm{O}_{2}$ gas in $\mathrm{C}_{6} \mathrm{D}_{6}$ in $100 \mathrm{~mL}$ Schlenk flasks. Conversions were determined after $24 \mathrm{~h}$ by ${ }^{31} \mathrm{P}\left\{{ }^{1} \mathrm{H}\right\}-\mathrm{NMR}$ spectroscopy. Although $\mathrm{PMe}_{3}$ is easily oxidized without any metal in presence of water and air, the stability of $\mathrm{PMe}_{3}$ against dry $\mathrm{O}_{2}$ is high as blank experiments under identical conditions but without catalysts led to a conversion of $\mathrm{PMe}_{3}<5 \%$. 


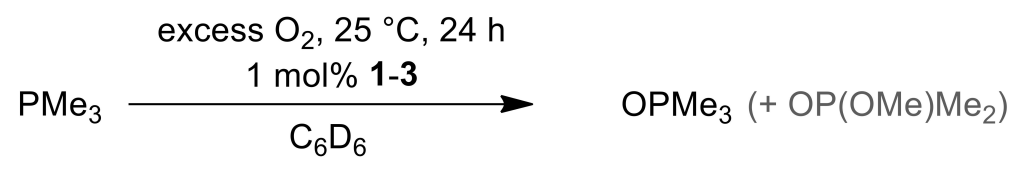

The highest conversion of trimethyl phosphane was observed for catalyst 2, bearing tert-butyl amide functionalities, with a phosphane oxide yield of $53 \%$ accompanied by $4 \%$ of the previously observed side product methyl dimethylphosphinate (Table 3) [36]. Catalyst 1, without hydrogen bond donors, selectively oxidized $46 \%$ of $\mathrm{PMe}_{3}$ to $\mathrm{OPMe}_{3}$ within $24 \mathrm{~h}$. Both values are comparable to other molybdenum dioxido systems [36]. This is in line with the formation of a weak hydrogen interaction, which is not sufficient to increase the reactivity. Interestingly, complex 3, equipped with a phenyl amide group, led only to $25 \%$ conversion $\left(23 \% \mathrm{OPMe}_{3}\right)$. This finding is corroborated by the solid-state structures where the $\mathrm{OPMe}_{3}$ molecule is retained by hydrogen bonding thereby decreasing catalytic reactivity. Another possibility is the formation of polynuclear compounds during the reaction, as observed in the synthesis of the peroxido complex 11 (vide supra). With more challenging substrates such as cyclooctene or also $\mathrm{SMe}_{2}$ no conversion was observed.

Table 3. Yield after $24 \mathrm{~h}$ in the aerobic oxidation of $\mathrm{PMe}_{3}$.

\begin{tabular}{ccccc}
\hline Product & - & $\mathbf{1}$ & $\mathbf{2}$ & $\mathbf{3}$ \\
\hline $\mathrm{OPMe}_{3}$ & $<5 \%$ & $46 \%$ & $53 \%$ & $23 \%$ \\
$\mathrm{OP}(\mathrm{OMe}) \mathrm{Me}_{2}$ & - & - & $4 \%$ & $2 \%$ \\
\hline
\end{tabular}

Conditions: $1 \mathrm{~mol} \%$ catalyst, $\mathrm{rt}, \mathrm{C}_{6} \mathrm{D}_{6}$, excess $\mathrm{O}_{2}$.

\section{Experimental Section}

\subsection{General}

Unless specified otherwise, experiments were performed under inert conditions using standard Schlenk equipment. Chemicals were purchased from commercial sources and used as received. No further purification or drying operations have been performed. The metal precursors $\left[\mathrm{MoO}_{2}(\mathrm{acac})_{2}\right][48]$ and $\left[\mathrm{MoO}_{2} \mathrm{Br}_{2} \text { (DMSO) }\right)_{2}$ [59] as well as the compound 3-(((benzyloxy)carbonyl)amino)propanoic acid [47] were synthesized according to published procedures. Solvents were purified via a Pure-Solv MD-4-EN solvent purification system from Innovative Technology, Inc. (Oldham, UK). Methanol was refluxed over activated magnesium for at least $24 \mathrm{~h}$ and then distilled prior to use. The ${ }^{1} \mathrm{H}-,{ }^{13} \mathrm{C}_{-},{ }^{31} \mathrm{P}-$ and HSQC-NMR spectra were recorded on a Bruker Avance III instrument at 300/75/121 MHz (Bruker, Billerica, MA, USA). Peaks are denoted as singlet (s), broad singlet (bs), doublet (d), doublet of doublets $(\mathrm{dd})$, doublet of triplets (dt), triplet $(\mathrm{t})$, triplet of doublets ( $\mathrm{td})$ and multiplet $(\mathrm{m})$. Used solvents and peak assignment are mentioned at the specific data sets. Electron impact mass spectroscopy (EI-MS) measurements have been performed with an Agilent 5973 MSD mass spectrometer with push rod (Agilent Technologies Inc., Santa Clara, CA, USA). Peaks are denoted as cationic mass peaks, and the unit is the according ion's mass/charge ratio. Gas chromatography mass spectroscopy (GC-MS) measurements have been performed with an Agilent 7890 A gas chromatograph (column type, Agilent 19091J-433, Agilent Technologies Inc., Santa Clara, CA, USA), coupled to an Agilent 5975 C mass spectrometer. Samples for infrared spectroscopy were measured on a Bruker Optics ALPHA FT-IR spectrometer (Bruker, Billerica, MA, USA). IR bands are reported with wavenumber $\left(\mathrm{cm}^{-1}\right)$ and intensities (s, strong; m, medium; w, weak). All elemental analyses were measured at the University of Technology of Graz, Institute of Inorganic Chemistry using an Elementar vario MICRO cube analyzer (Elementar, Langenselbold, Germany). 


\subsection{X-ray Diffraction Analyses}

Single-crystal X-ray diffraction analyses were measured on a BRUKER-AXS SMART APEX II diffractometer equipped with a CCD detector (Bruker-AXS, Karlsruhe, Germany). All measurements were performed using monochromatized $\mathrm{Mo}_{\alpha}$ radiation from an Incoatec microfocus sealed tube at $100 \mathrm{~K}$ (Tables S1 and S2). Absorption corrections were performed semi-empirical from equivalents. Structures were solved by direct methods (SHELXS-97) [60] and refined by full-matrix least-squares techniques against $F^{2}$ (SHELXL-2014/6) [61]. CCDC numbers 1865601-1865613 contain the supplementary crystallographic data for this paper. These data can be obtained free of charge from The Cambridge Crystallographic Data Centre via www.ccdc.cam.ac.uk/data_request/cif. Full experimental details for single-crystal X-ray diffraction analyses of all compounds are provided in the Supplementary Materials.

\subsection{Ligand Syntheses}

All ligands are stable towards air but slightly sensitive towards moisture. They can be stored in a desiccator over $\mathrm{P}_{2} \mathrm{O}_{5}$ for several weeks without decomposition.

\subsubsection{Synthesis of 2,4-Di-tert-butyl-6-((butylimino)methyl)phenol (HL1)}

Ligand HL1 was synthesized according to literature procedure [46]. Analytical data are consistent with literature, ${ }^{1} \mathrm{H}$ - and ${ }^{13} \mathrm{C}$-NMR shifts in $\mathrm{C}_{6} \mathrm{D}_{6}$ as well as IR absorption bands are given for comparison reasons. ${ }^{1} \mathrm{H}-\mathrm{NMR}\left(300 \mathrm{MHz}, \mathrm{C}_{6} \mathrm{D}_{6}, 25^{\circ} \mathrm{C}\right) \delta: 14.33(\mathrm{~s}, 1 \mathrm{H}, \mathrm{OH}), 7.82(\mathrm{~s}, 1 \mathrm{H}, \mathrm{CH}=\mathrm{N}), 7.58(\mathrm{~d}, 1 \mathrm{H}$, ArH), $7.00(\mathrm{~d}, 1 \mathrm{H}, \mathrm{ArH}), 3.15\left(\mathrm{td}, 2 \mathrm{H}, \mathrm{CH}_{2}\right), 1.67(\mathrm{~s}, 9 \mathrm{H}, t \mathrm{Bu}), 1.43-1.33\left(\mathrm{~m}, 2 \mathrm{H}, \mathrm{CH}_{2}\right), 1.35(\mathrm{~s}, 9 \mathrm{H}, t \mathrm{Bu})$, 1.26-1.14 (m, 2H, $\left.\mathrm{CH}_{2}\right), 0.79\left(\mathrm{t}, 3 \mathrm{H}, \mathrm{CH}_{3}\right) \mathrm{ppm} ;{ }^{13} \mathrm{C}-\mathrm{NMR}\left(75 \mathrm{MHz}, \mathrm{C}_{6} \mathrm{D}_{6}, 25^{\circ} \mathrm{C}\right) \delta: 165.89(\mathrm{C}=\mathrm{N}), 159.00$ (Ar-O), 140.03, 137.17, 126.78, 126.25, $118.72(\mathrm{Ar}), 59.40\left(\mathrm{CH}_{2}\right), 35.48,34.33(\mathrm{q}-\mathrm{tBu}), 33.25\left(\mathrm{CH}_{2}\right), 31.81$, $29.83(t \mathrm{Bu}), 20.63\left(\mathrm{CH}_{2}\right), 13.98\left(\mathrm{CH}_{3}\right) \mathrm{ppm}$. IR $\left(\mathrm{ATR}, \mathrm{cm}^{-1}\right) \delta: 3316(\mathrm{w}, \mathrm{OH}+\mathrm{NH}), 2955(\mathrm{w}, \mathrm{C}-\mathrm{H}), 1668$ $(\mathrm{m}, \mathrm{C}=\mathrm{O}), 1629(\mathrm{~m}, \mathrm{C}=\mathrm{N}), 1600(\mathrm{~s}), 1543(\mathrm{~s}), 1439(\mathrm{~s}), 1310(\mathrm{~m}), 1249(\mathrm{~m}), 828(\mathrm{~m}), 755(\mathrm{~s}), 693(\mathrm{~s}), 503$ (m); IR (ATR, cm ${ }^{-1}$ ) ṽ: 3437 (br w, OH), 2955 (s, C-H), 1632 (s, C=N), 1466 (s), 1440 (s), 1361 (m), 1273 (s) $1251(\mathrm{~s}), 1173(\mathrm{~s}), 827(\mathrm{~m}), 772(\mathrm{~m})$.

\subsubsection{Synthesis of N-(tert-Butyl)-3-((3,5-di-tert-butyl-2-hydroxybenzylidene)amino)-} propanamide (HL2)

For the synthesis of HL2, a three-step procedure was applied. In the first step, 1 equiv of 3-(((benzyloxy)carbonyl)amino)propanoic acid (10.00 g, $44.8 \mathrm{mmol})$ and 1 equiv $\mathrm{Et}_{3} \mathrm{~N}(6.2 \mathrm{~mL}$, $44.8 \mathrm{mmol}$ ) were dissolved in $100 \mathrm{~mL}$ of dry toluene and subsequently cooled to $-12{ }^{\circ} \mathrm{C}$ (ice $/ \mathrm{NaCl}$ bath). Subsequently, 1 equiv of ethyl chloroformate $(4.4 \mathrm{~mL}, 44.8 \mathrm{mmol})$ was added dropwise over 30 min while keeping the temperature below $-10{ }^{\circ} \mathrm{C}$. After stirring of the reaction solution at $-12{ }^{\circ} \mathrm{C}$ for $30 \mathrm{~min}$, 1 equiv of tert-butyl amine $(4.7 \mathrm{~mL}, 44.8 \mathrm{mmol})$ in $10 \mathrm{~mL}$ dry dichloromethane was added dropwise over $15 \mathrm{~min}$ while keeping the temperature below $-10^{\circ} \mathrm{C}$. Subsequently, the reaction mixture was stirred for $30 \mathrm{~min}$ at $-12{ }^{\circ} \mathrm{C}$, warmed to room temperature and finally stirred under reflux for $10 \mathrm{~min}$. The reaction was then stirred at room temperature overnight. The subsequent work-up was performed at ambient conditions. After addition of $200 \mathrm{~mL}$ chloroform, the reaction mixture was washed two times with saturated aqueous $\mathrm{NaHCO}_{3}$ solution and deionized water (100 $\mathrm{mL}$ each). The organic phase was dried over $\mathrm{MgSO}_{4}$ and evaporated in vacuo. The crude product was recrystallized from ethyl acetate to yield benzyl (3-oxo-3-(phenylamino)propyl)carbamate as a white crystalline solid $(68 \%, 8.53 \mathrm{~g})$.

In the second step, 1 equiv of benzyl (3-oxo-3-(phenylamino)propyl)carbamate $(4.67 \mathrm{~g}, 17.0 \mathrm{mmol})$ was dissolved in $100 \mathrm{~mL}$ of MeOH. Subsequently $15 \mathrm{w} \% \mathrm{Pd} / \mathrm{C}(0.70 \mathrm{~g})$ were added and the reaction mixture stirred under an $\mathrm{H}_{2}$ atmosphere (5 atm) overnight at room temperature. Filtration and evaporation of the filtrate in vacuo gave 3-amino- $N$-(tert-butyl)propanamide as light yellow oil $(94 \%$, $2.28 \mathrm{~g})$. In the final step, 1.1 equiv of 3-amino- $\mathrm{N}$-(tert-butyl)propanamide $(1.00 \mathrm{~g}, 6.9 \mathrm{mmol})$ were 
added to a solution of 1 equiv of 3,5-di-tert-butyl-2-hydroxybenzaldehyde ( $1.48 \mathrm{~g}, 6.3 \mathrm{mmol})$ in $5 \mathrm{~mL}$ of $\mathrm{MeOH}$. The resulting deep yellow solution was subsequently stirred at $50{ }^{\circ} \mathrm{C}$ for $3 \mathrm{~h}$. Evaporation of all volatiles in vacuo led to a deep yellow oil that solidified over the course of several days. Washing of the crude product twice with $5 \mathrm{~mL}$ of pentane gave $\mathrm{HL2}$ as bright yellow solid $(88 \%, 1.99 \mathrm{~g}$, overall yield 56\%). ${ }^{1} \mathrm{H}-\mathrm{NMR}\left(300 \mathrm{MHz}, \mathrm{C}_{6} \mathrm{D}_{6}, 25^{\circ} \mathrm{C}\right) \delta: 14.06(\mathrm{~s}, 1 \mathrm{H}, \mathrm{OH}), 7.90(\mathrm{~s}, 1 \mathrm{H}, \mathrm{CH}=\mathrm{N}), 7.56(\mathrm{~d}, 1 \mathrm{H}$, ArH). $6.96(\mathrm{~d}, 1 \mathrm{H}, \mathrm{ArH}), 4.86(\mathrm{bs}, 1 \mathrm{H}, \mathrm{NH}), 3.54\left(\mathrm{t}, 2 \mathrm{H}, \mathrm{CH}_{2}\right), 1.93\left(\mathrm{t}, 2 \mathrm{H}, \mathrm{CH}_{2}\right), 1.66(\mathrm{~s}, 9 \mathrm{H}, t \mathrm{Bu}), 1.30(\mathrm{~s}$, 9H, $t \mathrm{Bu}), 1.21(\mathrm{~s}, 9 \mathrm{H}, \mathrm{tBu}) \mathrm{ppm} ;{ }^{13} \mathrm{C}-\mathrm{NMR}\left(75 \mathrm{MHz}, \mathrm{C}_{6} \mathrm{D}_{6}, 25^{\circ} \mathrm{C}\right) \delta: 169.57(\mathrm{C}=\mathrm{O}), 167.33(\mathrm{C}=\mathrm{N}), 158.72$ (Ar-O), 140.23, 136.92, 126.93, 126.58, $118.62(\mathrm{Ar}), 55.81\left(\mathrm{CH}_{2}\right), 50.99(\mathrm{q}-\mathrm{tBu}), 38.68\left(\mathrm{CH}_{2}\right), 35.42,34.29$ (q- $t \mathrm{Bu}), 31.74,29.81,28.74(t \mathrm{Bu})$ ppm; EI-MS: $\mathrm{m} / z 360.4\left([\mathrm{M}]^{+}\right)$; IR (ATR, $\left.\mathrm{cm}^{-1}\right) \tilde{v}: 3322(\mathrm{w}, \mathrm{OH}+\mathrm{NH})$, 2952 (m, C-H), 1639 (s, C=O), 1629 (s, C=N), 1541 (s), 1438 (s), 1390 (m), 1276 (m).

\subsubsection{Synthesis of 3-((3,5-Di-tert-butyl-2-hydroxybenzylidene)amino)- $N$-phenylpropan-amide (HL3)}

For the synthesis of HL3, a two-step procedure was applied. In the first step, 3-amino- $N$-phenylpropanamide was synthesized following a published procedure (yield: 58\%) [62]. In the second step, 1 equiv of 3-amino- $\mathrm{N}$-phenylpropanamide $(1.45 \mathrm{~g}, 8.8 \mathrm{mmol})$ was added to a solution of 1 equiv of 3,5-di-tert-butyl-2-hydroxybenzaldehyde (2.07 g, $8.8 \mathrm{mmol})$ in $20 \mathrm{~mL}$ of MeOH. The resulting yellow solution was stirred at reflux temperature overnight and subsequently evaporated in vacuo. The crude product was washed thoroughly with pentane to give HL3 as pale yellow solid $(84 \%, 2.83 \mathrm{~g}, 48 \%$ overall yield). Crystals suitable for single-crystal X-ray diffraction analysis were obtained via crystallization from a concentrated $\mathrm{C}_{6} \mathrm{D}_{6}$ solution of $\mathbf{H L 3}$ at $25^{\circ} \mathrm{C} .{ }^{1} \mathrm{H}-\mathrm{NMR}(300 \mathrm{MHz}$, $\left.\mathrm{C}_{6} \mathrm{D}_{6}, 25^{\circ} \mathrm{C}\right) \delta: 14.02(\mathrm{~s}, 1 \mathrm{H}, \mathrm{OH}), 7.91(\mathrm{~s}, 1 \mathrm{H}, \mathrm{CH}=\mathrm{N}), 7.56(\mathrm{~d}, 1 \mathrm{H}, \mathrm{ArH}) .7 .56-7.50(\mathrm{~m}, 2 \mathrm{H}, \mathrm{ArH})$, 7.12-7.04 (m, 2H, ArH), $6.95(\mathrm{~d}, 1 \mathrm{H}, \mathrm{ArH}), 6.89-6.82(\mathrm{~m}, 1 \mathrm{H}, \mathrm{ArH}), 6.69(\mathrm{bs}, 1 \mathrm{H}, \mathrm{NH}), 3.54\left(\mathrm{t}, 2 \mathrm{H}, \mathrm{CH}_{2}\right)$, $2.01\left(\mathrm{t}, 2 \mathrm{H}, \mathrm{CH}_{2}\right), 1.65(\mathrm{~s}, 9 \mathrm{H}, t \mathrm{Bu}), 1.30(\mathrm{~s}, 9 \mathrm{H}, t \mathrm{Bu}), 1.21(\mathrm{~s}, 9 \mathrm{H}, t \mathrm{Bu}) \mathrm{ppm} ;{ }^{13} \mathrm{C}-\mathrm{NMR}\left(75 \mathrm{MHz}, \mathrm{C}_{6} \mathrm{D}_{6}\right.$, $\left.25^{\circ} \mathrm{C}\right) \delta: 168.69(\mathrm{C}=\mathrm{O}), 167.80(\mathrm{C}=\mathrm{N}), 158.75(\mathrm{Ar}-\mathrm{O}), 140.34,138.64,137.00,129.11,127.14,126.68,124.25$, 120.10, 118.57 (Ar), $55.1838 .23\left(\mathrm{CH}_{2}\right), 35.43,34.29(\mathrm{q}-t \mathrm{Bu}), 31.71,29.79(t \mathrm{Bu}) \mathrm{ppm}$; EI-MS: $\mathrm{m} / z 380.4$ $\left([\mathrm{M}]^{+}\right)$; IR (ATR, $\left.\mathrm{cm}^{-1}\right) \tilde{v}: 3316(\mathrm{w}, \mathrm{OH}+\mathrm{NH}), 2955(\mathrm{w}, \mathrm{C}-\mathrm{H}), 1668(\mathrm{~m}, \mathrm{C}=\mathrm{O}), 1629(\mathrm{~m}, \mathrm{C}=\mathrm{N}), 1600$ (s), 1543 (s), 1439 (s), 1310 (m), 1249 (m), 828 (m), 755 (s), 693 (s), 503 (m).

\subsection{Complex Syntheses}

All complexes except 4-6 are stable towards air but sensitive towards moisture and can be stored in a desiccator over $\mathrm{P}_{2} \mathrm{O}_{5}$ for several weeks without decomposition. Complex 4 is sensitive towards air and moisture and can be stored in an $\mathrm{N}_{2}$-filled glovebox for several weeks without decomposition; compounds 5 and $\mathbf{6}$ could not be isolated due to substantial decomposition during work-up.

\subsubsection{Alternative Synthesis of $\left[\mathrm{MoO}_{2}(\mathbf{L 1})_{2}\right](\mathbf{1})$}

For the synthesis of 1,1 equiv of $\left[\mathrm{MoO}_{2} \mathrm{Br}_{2}(\mathrm{DMSO})_{2}\right](610 \mathrm{mg}, 1.37 \mathrm{mmol})$ was suspended in dry toluene $(10 \mathrm{~mL})$. Subsequently, 2 equiv of $\mathbf{H L 1}(800 \mathrm{mg}, 2.74 \mathrm{mmol})$ as well as 2.5 equiv of $\mathrm{NEt}_{3}$ $\left(48 \mu \mathrm{L}, 3.43 \mathrm{mmol}\right.$ ) were added and the deep orange reaction mixture stirred at $60^{\circ} \mathrm{C}$ for $18 \mathrm{~h}$. The orange reaction mixture was subsequently concentrated in vacuo and stored at $-25^{\circ} \mathrm{C}$ for $24 \mathrm{~h}$. The precipitate was filtered off and washed with little dry toluene and subsequently twice with dry pentane to give 1 as a yellow microcrystalline powder $(57 \%, 550 \mathrm{mg})$. Crystals suitable for single-crystal X-ray diffraction analysis were obtained via crystallization from the residual filtrate at $5{ }^{\circ} \mathrm{C}\left(\mathbf{1} \cdot \mathrm{NEt}_{3} \cdot \mathrm{HBr}\right)$. Analytical data is consistent with the literature [16], ${ }^{1} \mathrm{H}$ - and ${ }^{13} \mathrm{C}-\mathrm{NMR}$ shifts in $\mathrm{C}_{6} \mathrm{D}_{6}$ as well as IR data is given for comparison reasons. ${ }^{1} \mathrm{H}-\mathrm{NMR}\left(300 \mathrm{MHz}, \mathrm{C}_{6} \mathrm{D}_{6}, 25^{\circ} \mathrm{C}\right.$, major isomer) $\delta: 7.85(\mathrm{~s}, 2 \mathrm{H}$, $\mathrm{CH}=\mathrm{N}), 7.72(\mathrm{~d}, 2 \mathrm{H}, \mathrm{ArH}), 7.12(\mathrm{~d}, 2 \mathrm{H}, \mathrm{ArH}), 3.50-3.29\left(\mathrm{~m}, 4 \mathrm{H}, \mathrm{CH}_{2}\right), 1.66(\mathrm{~s}, 18 \mathrm{H}, t \mathrm{Bu}), 1.66-1.16(\mathrm{~m}$, $\left.4 \mathrm{H}, \mathrm{CH}_{2}\right), 1.30(\mathrm{~s}, 18 \mathrm{H}, \mathrm{tBu}), 1.05-0.98\left(\mathrm{~m}, 4 \mathrm{H}, \mathrm{CH}_{2}\right), 0.69\left(\mathrm{t}, 6 \mathrm{H}, \mathrm{CH}_{3}\right) \mathrm{ppm} ;{ }^{13} \mathrm{C}-\mathrm{NMR}\left(75 \mathrm{MHz}, \mathrm{C}_{6} \mathrm{D}_{6}\right.$, $25^{\circ} \mathrm{C}$, major isomer, $1 \mathrm{Ar}$ concealed by solvent) $\delta: 167.15(\mathrm{CH}=\mathrm{N}), 161.15(\mathrm{Ar}-\mathrm{O}), 142.04,139.60,129.64$, 122.16 (Ar), $60.32\left(\mathrm{CH}_{2}\right), 35.60,34.40(\mathrm{q}-\mathrm{tBu}), 33.68\left(\mathrm{CH}_{2}\right), 31.61,30.35(t \mathrm{Bu}), 20.68\left(\mathrm{CH}_{2}\right), 13.84\left(\mathrm{CH}_{3}\right)$ ppm; IR (ATR, cm ${ }^{-1}$ ): v 2957 (m, C-H), 1628 (s, C=N), 1439 (m), 1270 (s), 1249 (s), 917 (m, Mo=O), 904 $(\mathrm{s}, \mathrm{Mo}=\mathrm{O}), 844(\mathrm{~s}), 754(\mathrm{~m}), 552(\mathrm{~s}, \mathrm{Mo}-\mathrm{O}), 431(\mathrm{~m})$. 


\subsubsection{Synthesis of $\left[\mathrm{MoO}_{2}(\mathbf{L} 2)_{2}\right](2)$}

For the synthesis of 2, 2 equiv of HL2 $(150 \mathrm{mg}, 0.42 \mathrm{mmol})$ as well as 1 equiv of $\left[\mathrm{MoO}_{2}(\mathrm{acac})_{2}\right]$ $(68 \mathrm{mg}, 0.21 \mathrm{mmol})$ were dissolved in dry $\mathrm{MeOH}(5 \mathrm{~mL})$. The deep orange reaction mixture was heated to $50^{\circ} \mathrm{C}$ and stirred for $18 \mathrm{~h}$, whereupon a bright yellow precipitate formed. The mixture was cooled to $5{ }^{\circ} \mathrm{C}$ for $2 \mathrm{~h}$ and the precipitate subsequently filtered off and washed with a small portion of cold dry $\mathrm{MeOH}$ as well as cold dry pentane. Drying in vacuo gave 2 as a bright yellow microcrystalline solid $(65 \%, 116 \mathrm{mg})$. Crystals suitable for single-crystal X-ray diffraction analysis were obtained via recrystallization from a concentrated $\mathrm{MeCN}$ solution at $-35^{\circ} \mathrm{C}(2 \cdot 2 \mathrm{MeCN}) .{ }^{1} \mathrm{H}-\mathrm{NMR}\left(300 \mathrm{MHz}, \mathrm{C}_{6} \mathrm{D}_{6}\right.$, $25^{\circ} \mathrm{C}$, major isomer (symm.)) $\delta: 8.02(\mathrm{~s}, 2 \mathrm{H}, \mathrm{CH}=\mathrm{N}), 7.67(\mathrm{~d}, 2 \mathrm{H}, \mathrm{ArH}), 7.12(\mathrm{~d}, 2 \mathrm{H}, \mathrm{ArH}), 6.12(\mathrm{bs}$, 2H, NH), 3.70-3.60 (m, 2H, $\left.\mathrm{CH}_{2}\right), 3.57-3.42\left(\mathrm{~m}, 2 \mathrm{H}, \mathrm{CH}_{2}\right), 3.12-2.99\left(\mathrm{~m}, 2 \mathrm{H}, \mathrm{CH}_{2}\right), 2.23-2.12(\mathrm{~m}, 2 \mathrm{H}$, $\left.\mathrm{CH}_{2}\right), 1.56(\mathrm{~s}, 18 \mathrm{H}, t \mathrm{Bu}), 1.26(\mathrm{~s}, 18 \mathrm{H}, t \mathrm{Bu}), 1.04(\mathrm{~s}, 18 \mathrm{H}, t \mathrm{Bu}) \mathrm{ppm} ;{ }^{1} \mathrm{H}-\mathrm{NMR}\left(300 \mathrm{MHz}, \mathrm{C}_{6} \mathrm{D}_{6}, 25^{\circ} \mathrm{C}\right.$, minor isomer (asymm.)) 8: $8.22(\mathrm{~s}, 1 \mathrm{H}, \mathrm{CH}=\mathrm{N}), 7.80(\mathrm{~s}, 1 \mathrm{H}, \mathrm{CH}=\mathrm{N}), 7.63-7.61(\mathrm{~m}, 2 \mathrm{H}, \mathrm{ArH}), 7.01$ ("d", 2H, ArH), 6.05 (bs, 1H, NH), 5.80 (bs, 1H, NH), 4.47-4.38 (m, 1H, $\left.\mathrm{CH}_{2}\right), 3.98-3.85\left(\mathrm{~m}, 1 \mathrm{H}, \mathrm{CH}_{2}\right)$, 3.57-3.42 (m, 1H, CH $), 3.38-3.26\left(\mathrm{~m}, 1 \mathrm{H}, \mathrm{CH}_{2}\right), 2.56-2.40\left(\mathrm{~m}, 2 \mathrm{H}, \mathrm{CH}_{2}\right), 2.18-2.07\left(\mathrm{~m}, 1 \mathrm{H}, \mathrm{CH}_{2}\right), 1.64$ $(\mathrm{s}, 9 \mathrm{H}, t \mathrm{Bu}), 1.30(\mathrm{~s}, 9 \mathrm{H}, t \mathrm{Bu}), 1.22(\mathrm{~s}, 9 \mathrm{H}, t \mathrm{Bu}), 1.21(\mathrm{~s}, 9 \mathrm{H}, t \mathrm{Bu}), 1.15(\mathrm{~s}, 9 \mathrm{H}, t \mathrm{Bu}), 1.04(\mathrm{~s}, 9 \mathrm{H}, t \mathrm{Bu})$, ppm; ${ }^{13} \mathrm{C}-\mathrm{NMR}\left(75 \mathrm{MHz}, \mathrm{C}_{6} \mathrm{D}_{6}, 25{ }^{\circ} \mathrm{C}\right.$, major isomer (symm.) $) \delta: 169.42(\mathrm{C}=\mathrm{O}), 168.29(\mathrm{CH}=\mathrm{N}), 159.13$ (Ar-O), 142.87, 139.64, 130.17, 129.60, $121.69(\mathrm{Ar}), 58.89\left(\mathrm{CH}_{2}\right), 50.80(\mathrm{q}-\mathrm{tBu}), 40.31\left(\mathrm{CH}_{2}\right), 35.60,34.40$ (q-tBu) 31.50, 30.65, 28.52 (tBu) ppm; IR (ATR, $\mathrm{cm}^{-1}$ ) v: $3375(\mathrm{w}, \mathrm{NH}), 2961(\mathrm{~m}, \mathrm{C}-\mathrm{H}), 1676(\mathrm{~m}, \mathrm{C}=\mathrm{O})$, $1628(\mathrm{C}=\mathrm{N}, \mathrm{s}), 1524(\mathrm{~m}), 1442(\mathrm{~m}), 1361(\mathrm{~m}), 1248(\mathrm{~s}), 912(\mathrm{sh}, \mathrm{s}, \mathrm{Mo}=\mathrm{O}), 898(\mathrm{~s}, \mathrm{Mo}=\mathrm{O}), 842(\mathrm{~s}), 752$ (m), 549 (s, Mo-O), $483(\mathrm{~m}), 436(\mathrm{~m})$; EI-MS $(70 \mathrm{eV}) \mathrm{m} / \mathrm{z}: 848.7[\mathrm{M}]^{+}, 832.7\left[\mathrm{M}-\mathrm{O}^{+}\right.$; Anal. calcd. for $\mathrm{C}_{44} \mathrm{H}_{70} \mathrm{MoN}_{4} \mathrm{O}_{6} \cdot 0.5 \mathrm{CH}_{3} \mathrm{OH}: \mathrm{C}, 61.93 ; \mathrm{H}, 8.41 ; \mathrm{N}, 6.49$. Found: $\mathrm{C}, 61.61, \mathrm{H}, 8.01 ; \mathrm{N}, 6.73 \%$.

\subsubsection{Synthesis of $\left[\mathrm{MoO}_{2}(\mathrm{~L} 3)_{2}\right](3)$}

For the synthesis of 3, 2 equiv of HL3 $(765 \mathrm{mg}, 2.01 \mathrm{mmol})$ were suspended in a small portion of dry $\mathrm{MeOH}$ and mixed with 2.5 equiv of $\mathrm{NEt}_{3}(0.35 \mathrm{~mL}, 2.52 \mathrm{mmol})$. Subsequently, a solution of 1 equiv $\left[\mathrm{MoO}_{2} \mathrm{Cl}_{2}\right](200 \mathrm{mg}, 1.01 \mathrm{mmol})$ in the same solvent $(5 \mathrm{~mL})$ was added dropwise to the mixture. The orange-red reaction mixture was stirred for $18 \mathrm{~h}$ whereupon yellow solids precipitated. The mixture was stored at $-25^{\circ} \mathrm{C}$ overnight and the precipitate subsequently filtered off and washed with small portions of dry $\mathrm{MeOH}$ and $n$-pentane. Removal of all volatiles in vacuo yielded 3 as a bright yellow solid $(66 \%, 638 \mathrm{mg})$. Crystals suitable for single-crystal X-ray diffraction analysis were obtained via recrystallization from a concentrated $\mathrm{MeOH}$ solution at $-35^{\circ} \mathrm{C}(3 \cdot 4 \mathrm{MeOH}) .{ }^{1} \mathrm{H}-\mathrm{NMR}\left(300 \mathrm{MHz}, \mathrm{C}_{6} \mathrm{D}_{6}\right.$, $25^{\circ} \mathrm{C}$, major isomer (symm.)) $\delta: 8.09(\mathrm{~s}, 2 \mathrm{H}, \mathrm{NH}), 7.91(\mathrm{~s}, 2 \mathrm{H}, \mathrm{CH}=\mathrm{N}), 7.61(\mathrm{~d}, 2 \mathrm{H}, \mathrm{ArH}), 7.43-7.36(\mathrm{~m}$, $4 \mathrm{H}, \mathrm{ArH}), 6.94-6.67(\mathrm{~m}, 8 \mathrm{H}, \mathrm{ArH}), 3.73-3.61\left(\mathrm{~m}, 2 \mathrm{H}, \mathrm{CH}_{2}\right), 3.48-3.37\left(\mathrm{~m}, 2 \mathrm{H}, \mathrm{CH}_{2}\right), 3.13-2.97(\mathrm{~m}, 2 \mathrm{H}$, $\left.\mathrm{CH}_{2}\right), 2.35-2.24\left(\mathrm{~m}, 2 \mathrm{H}, \mathrm{CH}_{2}\right), 1.57(\mathrm{~s}, 18 \mathrm{H}, t \mathrm{Bu}), 1.12(\mathrm{~s}, 18 \mathrm{H}, t \mathrm{Bu}) \mathrm{ppm} .{ }^{13} \mathrm{C}-\mathrm{NMR}$ (HSQC $300 / 75 \mathrm{MHz}$, $\mathrm{C}_{6} \mathrm{D}_{6}, 25^{\circ} \mathrm{C}$, major isomer (symm.), q-C obscured) $\delta: 168.72(\mathrm{CH}=\mathrm{N}), 130.89,128.64,128.51,123.69$, 119.38 (Ar), 59.26, $40.29\left(\mathrm{CH}_{2}\right), 31.02,30.42(t \mathrm{Bu})$; IR (ATR, $\left.\mathrm{cm}^{-1}\right)$ : ṽ: $3320(\mathrm{~m}, \mathrm{NH}), 2952(\mathrm{~m}, \mathrm{C}-\mathrm{H}), 1666$ (s, C=O), 1619 (s, C=N), 1601 (s), 1542 (s), 1442 (s), 1270 (m), 1176 (m), 929 (w), 914 (sh, s, Mo=O), 900 $(\mathrm{s}, \mathrm{Mo}=\mathrm{O}), 846(\mathrm{~s}), 752(\mathrm{~s}), 692(\mathrm{~m}), 549(\mathrm{~m}, \mathrm{Mo}-\mathrm{O}), 496(\mathrm{~m}), 432(\mathrm{w})$; Anal. calcd. for $\mathrm{C}_{48} \mathrm{H}_{62} \mathrm{MoN}_{4} \mathrm{O}_{6}$ : C, 65.00; H, 7.05; N, 6.32. Found: C, 64.98, H, 7.39; N, 6.32\%.

\subsubsection{Synthesis of $\left[\mathrm{MoO}\left(\mathrm{PMe}_{3}\right)(\mathbf{L 1})_{2}\right](4)$}

For the synthesis of 4,1 equiv of $1(125 \mathrm{mg}, 0.18 \mathrm{mmol})$ was dissolved in dry toluene $(5 \mathrm{~mL})$ in a Schlenk tube under $\mathrm{N}_{2}$ atmosphere. Subsequently 5 equiv of $\mathrm{PMe}_{3}(95 \mu \mathrm{L}, 0.90 \mathrm{mmol})$ were added, whereupon the reaction mixture changed color to reddish brown. The reaction mixture was stirred for $18 \mathrm{~h}$ at room temperature. Subsequently all volatiles were evaporated in vacuo, cold dry heptane $(3 \mathrm{~mL})$ was added to the crude dark residue and insoluble $\mathrm{OPMe}_{3}$ was removed via filtration over a glass frit packed with Celite. Evaporation of all volatiles gave 4 as a red-brown solid $(80 \%, 110 \mathrm{mg})$. ${ }^{1} \mathrm{H}-\mathrm{NMR}\left(300 \mathrm{MHz}, \mathrm{C}_{6} \mathrm{D}_{6}, 25^{\circ} \mathrm{C}\right.$, major isomer) $\delta: 8.04(\mathrm{~s}, 1 \mathrm{H}, \mathrm{CH}=\mathrm{N}), 7.90(\mathrm{~s}, 1 \mathrm{H}, \mathrm{CH}=\mathrm{N}), 7.50(\mathrm{~d}, 1 \mathrm{H}$, $\operatorname{ArH}), 7.40(\mathrm{~d}, 1 \mathrm{H}, \mathrm{ArH}), 7.18(\mathrm{~d}, 1 \mathrm{H}, \mathrm{ArH}), 7.03(\mathrm{~d}, 1 \mathrm{H}, \mathrm{ArH}), 4.22-3.86\left(\mathrm{~m}, 3 \mathrm{H}, \mathrm{CH}_{2}\right), 3.77-3.63(\mathrm{~m}, 1 \mathrm{H}$, 
$\left.\mathrm{CH}_{2}\right), 2.59-2.42\left(\mathrm{~m}, 1 \mathrm{H}, \mathrm{CH}_{2}\right), 2.22-1.87\left(\mathrm{~m}, 3 \mathrm{H}, \mathrm{CH}_{2}\right), 1.45-1.20\left(\mathrm{~m}, 4 \mathrm{H}, \mathrm{CH}_{2}\right), 1.36(\mathrm{~s}, 27 \mathrm{H}, t \mathrm{Bu}), 1.29$ $(\mathrm{s}, 9 \mathrm{H}, t \mathrm{Bu}), 1.01-0.82\left(\mathrm{~m}, 6 \mathrm{H}, \mathrm{CH}_{3}\right), 0.92\left(\mathrm{~d}, 9 \mathrm{H}, \mathrm{PMe}_{3}\right) \mathrm{ppm} ;{ }^{13} \mathrm{C}-\mathrm{NMR}\left(75 \mathrm{MHz}, \mathrm{C}_{6} \mathrm{D}_{6}, 25{ }^{\circ} \mathrm{C}\right.$, major isomer, 1 Ar obscured) $\delta:$ 168.10, $165.93(\mathrm{CH}=\mathrm{N}), 162.38,162.24(\mathrm{Ar}-\mathrm{O}), 140.24,138.53,136.44,136.26$, 131.03, 129.90, 129.24, 121.25, 121.05 (Ar), 35.64, $35.48(\mathrm{q}-\mathrm{tBu}), 35.28\left(\mathrm{CH}_{2}\right), 34.26,34.01(\mathrm{q}-t \mathrm{Bu}) 33.07$ $\left(\mathrm{CH}_{2}\right) 31.89,31.79,30.12,29.99(t \mathrm{Bu}), 21.42,20.53,18.61,17.70\left(\mathrm{CH}_{2}\right), 16.84,16.59\left(\mathrm{CH}_{3}\right), 14.25\left(\mathrm{~d}, \mathrm{PMe}_{3}\right)$ ppm; ${ }^{31} \mathrm{P}\left\{{ }^{1} \mathrm{H}\right\}$-NMR (121 MHz, $\mathrm{C}_{6} \mathrm{D}_{6}, 25^{\circ} \mathrm{C}$, major isomer): -3.04 ppm; IR (ATR, $\left.\mathrm{cm}^{-1}\right)$ v: $2952(\mathrm{~s}$, C-H), 1611 (s, C=N), 1433 (s), 1308 (m), 1254 (s), 952 (m), 911 (s, Mo=O), 836 (s), 745 (m), 524 (w, Mo-O), 443 (m); Anal. calcd for $\mathrm{C}_{41} \mathrm{H}_{69} \mathrm{MoN}_{2} \mathrm{O}_{3} \mathrm{P}: \mathrm{C}, 64.38 ; \mathrm{H}, 9.09 ; \mathrm{N}, 3.66$ found: $\mathrm{C}, 64.32 ; \mathrm{H}, 8.83 ; \mathrm{N}, 3.57 \%$.

\subsubsection{Characterization of $\left[\mathrm{MoO}\left(\mathrm{PMe}_{3}\right)(\mathrm{L} 2)_{2}\right](5)$}

For the characterization of 5, 5 equiv of $\mathrm{PMe}_{3}(10 \mu \mathrm{L}, 0.10 \mathrm{mmol})$ were added to a solution of 1 equiv of $2(20 \mathrm{mg}, 0.02 \mathrm{mmol})$ in dry $\mathrm{C}_{6} \mathrm{D}_{6}(0.5 \mathrm{~mL})$, whereupon the solution turned reddish brown. NMR spectra $\left({ }^{1} \mathrm{H},{ }^{13} \mathrm{C},{ }^{31} \mathrm{P}\right)$ were recorded after $18 \mathrm{~h} .{ }^{1} \mathrm{H}-\mathrm{NMR}\left(300 \mathrm{MHz}, \mathrm{C}_{6} \mathrm{D}_{6}, 25^{\circ} \mathrm{C}\right.$, major isomer $)$ $\delta: 8.19(\mathrm{~s}, 1 \mathrm{H}, \mathrm{CH}=\mathrm{N}), 8.08(\mathrm{~s}, 1 \mathrm{H}, \mathrm{CH}=\mathrm{N}), 7.45(\mathrm{~d}, 1 \mathrm{H}, \mathrm{ArH}), 7.38(\mathrm{~d}, 1 \mathrm{H}, \mathrm{ArH}), 7.18(\mathrm{~d}, 1 \mathrm{H}, \mathrm{ArH}), 7.00$ (d, 1H, ArH), 6.86 (br s, 1H, NH), $5.71(\mathrm{br} \mathrm{s}, 1 \mathrm{H}, \mathrm{NH}), 4.57-4.50\left(\mathrm{~m}, 2 \mathrm{H}, \mathrm{CH}_{2}\right), 4.38-4.13\left(\mathrm{~m}, 2 \mathrm{H}, \mathrm{CH}_{2}\right)$, 3.46-3.31 (m, 1H, $\left.\mathrm{CH}_{2}\right), 3.28-3.11\left(\mathrm{~m}, 1 \mathrm{H}, \mathrm{CH}_{2}\right), 3.07-2.92\left(\mathrm{~m}, 1 \mathrm{H}, \mathrm{CH}_{2}\right), 2.71-2.60\left(\mathrm{~m}, 1 \mathrm{H}, \mathrm{CH}_{2}\right), 1.33(\mathrm{~s}$, $9 \mathrm{H}, t \mathrm{Bu}), 1.32(\mathrm{~s}, 9 \mathrm{H}, t \mathrm{Bu}), 1.31(\mathrm{~s}, 9 \mathrm{H}, t \mathrm{Bu}), 1.29(\mathrm{~s}, 9 \mathrm{H}, t \mathrm{Bu}), 1.28(\mathrm{~s}, 9 \mathrm{H}, t \mathrm{Bu}), 1.21(\mathrm{~s}, 9 \mathrm{H}, t \mathrm{Bu}), 0.81(\mathrm{~d}$, 9H, coord. $\left.\mathrm{PMe}_{3}\right) \mathrm{ppm} ;{ }^{13} \mathrm{C}-\mathrm{NMR}\left(75 \mathrm{MHz}, \mathrm{C}_{6} \mathrm{D}_{6}, 25^{\circ} \mathrm{C}\right.$, major isomer) $\delta: 170.24,169.82(\mathrm{C}=\mathrm{O}), 169.33$ $(\mathrm{C}=\mathrm{N}), 165.78(\mathrm{Ar}-\mathrm{O}), 163.48(\mathrm{C}=\mathrm{N}), 161.42(\mathrm{Ar}-\mathrm{O}), 139.57,139.54,138.33,137.04,136.93,131.69,130.17$, 129.61, 121.18, 121.10 (Ar), 69.16, $64.34\left(\mathrm{CH}_{2}\right)$, 50.94, 50.91 (q-tBu), 39.95, $39.14\left(\mathrm{CH}_{2}\right), 35.51,35.36,34.27$, 33.95 (q-tBu), 31.80, 31.69, 29.95, 29.84, 28.96, $28.76(\mathrm{tBu}), 16.51$ (d, coord. $\left.\mathrm{PMe}_{3}\right) \mathrm{ppm} ;{ }^{31} \mathrm{P}\left\{{ }^{1} \mathrm{H}\right\}-\mathrm{NMR}$ (121 MHz, $\mathrm{C}_{6} \mathrm{D}_{6}, 25^{\circ} \mathrm{C}$, major isomer): $-5.32 \mathrm{ppm}$.

\subsubsection{Synthesis of $\left[\mathrm{MoO}\left(\mathrm{O}_{2}\right)(\mathbf{L 1})_{2}\right](\mathbf{9})$}

For the synthesis of 9,1 equiv of 4 ( $30 \mathrm{mg}, 0.04 \mathrm{mmol})$ was dissolved in dry toluene $(3 \mathrm{~mL})$ in a Schlenk tube under $\mathrm{O}_{2}$ atmosphere (1.5 atm). Subsequently, the reaction mixture was stirred for $18 \mathrm{~h}$ at room temperature whereupon the color gradually changed to dark orange. After removal of all volatiles in vacuo, $3 \mathrm{~mL}$ of cold dry heptane were added to the crude dark orange residue and insoluble $\mathrm{OPMe}_{3}$ was removed via filtration over a glass frit packed with Celite. Evaporation in vacuo gave 9 as an orange solid (90\%, $25 \mathrm{mg})$. Alternatively, 9 is accessible directly from $\mathbf{1}$. Thus, 1 equiv of 1 $(120 \mathrm{mg}, 0.17 \mathrm{mmol})$ was dissolved in dry toluene $(5 \mathrm{~mL})$. After addition of 3 equiv of $\mathrm{PMe}_{3}$ in toluene ( $0.51 \mathrm{mmol}, 0.5 \mathrm{~mL} 1 \mathrm{M}$ solution), the reaction solution was stirred under an $\mathrm{O}_{2}$ atmosphere $(1.5 \mathrm{~atm})$ for $18 \mathrm{~h}$ at room temperature. The reaction mixture was subsequently evaporated to dryness; cold dry heptane $(5 \mathrm{~mL})$ was added and residual $\mathrm{OPMe}_{3}$ was removed via filtration through a glass frit packed with Celite. The filtrate was subsequently stored at $-35^{\circ} \mathrm{C}$ overnight, whereupon residual traces of 1 precipitated. After removal of the precipitate via filtration and evaporation of the filtrate, 9 was obtained as an orange solid $(84 \%, 103 \mathrm{mg})$. Crystals suitable for single-crystal X-ray diffraction analysis were obtained via slow evaporation of a concentrated benzene solution at room temperature (9). ${ }^{1} \mathrm{H}-\mathrm{NMR}\left(300 \mathrm{MHz}, \mathrm{C}_{6} \mathrm{D}_{6}, 25{ }^{\circ} \mathrm{C}\right.$, major isomer) $\delta: 8.05(\mathrm{~s}, 1 \mathrm{H}, \mathrm{CH}=\mathrm{N}), 8.02(\mathrm{~s}, 1 \mathrm{H}, \mathrm{CH}=\mathrm{N}), 7.67(\mathrm{~d}$, $1 \mathrm{H}, \mathrm{ArH}), 7.51(\mathrm{~d}, 1 \mathrm{H}, \mathrm{ArH}), 7.09(\mathrm{~d}, 1 \mathrm{H}, \mathrm{ArH}), 7.07(\mathrm{~d}, 1 \mathrm{H}, \mathrm{ArH}), 5.08-4.99\left(\mathrm{~m}, 1 \mathrm{H}, \mathrm{CH}_{2}\right), 4.88-4.79(\mathrm{~m}$, $\left.1 \mathrm{H}, \mathrm{CH}_{2}\right), 3.80-3.71\left(\mathrm{~m}, 2 \mathrm{H}, \mathrm{CH}_{2}\right), 2.31-1.82\left(\mathrm{~m}, 4 \mathrm{H}, \mathrm{CH}_{2}\right), 1.49-1.08\left(\mathrm{~m}, 4 \mathrm{H}, \mathrm{CH}_{2}\right), 1.34(\mathrm{~s}, 9 \mathrm{H}, t \mathrm{Bu})$, $1.29(\mathrm{~s}, 18 \mathrm{H}, t \mathrm{Bu}), 1.19(\mathrm{~s}, 9 \mathrm{H}, t \mathrm{Bu}), 0.92-0.63\left(\mathrm{~m}, 6 \mathrm{H}, \mathrm{CH}_{3}\right) \mathrm{ppm} ;{ }^{13} \mathrm{C}-\mathrm{NMR}\left(75 \mathrm{MHz}, \mathrm{C}_{6} \mathrm{D}_{6}, 2{ }^{\circ} \mathrm{C}\right.$, major isomer) $\delta: 167.81,167.29(\mathrm{CH}=\mathrm{N}), 162.37,160.66(\mathrm{Ar}-\mathrm{O}), 139.70,139.61,139.26,138.97,132.01,129.16$, $128.89,122.04,121.88,66.70,62.29\left(\mathrm{CH}_{2}\right), 35.07,34.95,34.16(\mathrm{q}-\mathrm{tBu}), 34.12\left(\mathrm{CH}_{2}\right), 34.03(\mathrm{q}-\mathrm{tBu}), 31.79$ $\left(\mathrm{CH}_{2}\right), 31.63,31.50,29.75,29.63(\mathrm{tBu}), 20.71,20.68\left(\mathrm{CH}_{2}\right), 18.50,14.05\left(\mathrm{CH}_{3}\right) \mathrm{ppm} ; \mathrm{IR}\left(\mathrm{ATR}, \mathrm{cm}^{-1}\right) \tilde{v}: 2954$ (s, C-H), 1613 (s, C=N), 1438 (m), 1413 (m), 1253 (s), 927 (s, O-O), 915 (s, Mo=O), 841 (s), 750 (w), 540 (w, Mo-O); Anal. calcd for $\mathrm{C}_{38} \mathrm{H}_{60} \mathrm{MoN}_{2} \mathrm{O}_{5}: \mathrm{C}, 63.32 ; \mathrm{H}, 8.39 ; \mathrm{N}, 3.89$ Found: $\mathrm{C}, 63.81 ; \mathrm{H}, 8.19 ; \mathrm{N}, 3.82 \%$. 


\subsubsection{Synthesis of $\left[\mathrm{MoO}\left(\mathrm{O}_{2}\right)(\mathbf{L} 2)_{2}\right](\mathbf{1 0})$}

For the synthesis of 10, 3 equiv of $\mathrm{PMe}_{3}(18 \mu \mathrm{L}, 0.18 \mathrm{mmol})$ were added to a solution of 1 equiv of 2 (50 mg, $0.06 \mathrm{mmol})$ in dry toluene $(3 \mathrm{~mL})$, containing $3 \AA$ molecular sieves, and subsequently stirred under an $\mathrm{O}_{2}$ atmosphere $(1.5 \mathrm{~atm})$ for $18 \mathrm{~h}$ at room temperature. The reaction mixture was subsequently cooled to $5{ }^{\circ} \mathrm{C}$, filtered and evaporated in vacuo. The resulting orange residue was dissolved in a minimum amount of dry acetonitrile, layered with dry heptane and stored in a freezer at $-35^{\circ} \mathrm{C}$ for $24 \mathrm{~h}$. The orange precipitate was filtered off and dried to afford $\mathbf{1 0}$ as an orange solid $(55 \%, 28 \mathrm{mg})$. Single crystals suitable for X-ray diffraction analysis were obtained from concentrated $\mathrm{MeCN}(\mathbf{1 0})$ or benzene $\left(\mathbf{1 0} \cdot \mathrm{OPMe}_{3}\right)$ solutions at $-35^{\circ} \mathrm{C}$ and room temperature, respectively. ${ }^{1} \mathrm{H}-\mathrm{NMR}$ $\left(300 \mathrm{MHz}, \mathrm{C}_{6} \mathrm{D}_{6}, 25^{\circ} \mathrm{C}\right) \delta: 8.53(\mathrm{~s}, 1 \mathrm{H}, \mathrm{CH}=\mathrm{N}), 8.38(\mathrm{~s}, 1 \mathrm{H}, \mathrm{CH}=\mathrm{N}), 7.60(\mathrm{~d}, 1 \mathrm{H}, \mathrm{ArH}), 7.45(\mathrm{~d}, 1 \mathrm{H}, \mathrm{ArH})$, $7.09(\mathrm{~d}, 1 \mathrm{H}, \mathrm{ArH}), 7.02(\mathrm{~d}, 1 \mathrm{H}, \mathrm{ArH}), 5.96(\mathrm{bs}, 1 \mathrm{H}, \mathrm{NH}), 5.50\left(\mathrm{dt}, 1 \mathrm{H}, \mathrm{CH}_{2}\right), 5.40(\mathrm{bs}, 1 \mathrm{H}, \mathrm{NH}), 5.10(\mathrm{dt}$, $\left.1 \mathrm{H}, \mathrm{CH}_{2}\right), 4.49\left(\mathrm{td}, 1 \mathrm{H}, \mathrm{CH}_{2}\right), 4.26\left(\mathrm{td}, 1 \mathrm{H}, \mathrm{CH}_{2}\right), 3.26-3.01\left(\mathrm{~m}, 2 \mathrm{H}, \mathrm{CH}_{2}\right), 2.61-2.49\left(\mathrm{~m}, 2 \mathrm{H}, \mathrm{CH}_{2}\right), 1.33$ $(\mathrm{s}, 9 \mathrm{H}, t \mathrm{Bu}), 1.21(2 \mathrm{~s}, 9 \mathrm{H}, t \mathrm{Bu}), 1.21(\mathrm{~s}, 9 \mathrm{H}, t \mathrm{Bu}), 1.20(\mathrm{~s}, 9 \mathrm{H}, t \mathrm{Bu}), 1.11(\mathrm{~s}, 9 \mathrm{H}, t \mathrm{Bu}), 1.05(\mathrm{~s}, 9 \mathrm{H}, t \mathrm{Bu}), \mathrm{ppm}$; ${ }^{13} \mathrm{C}-\mathrm{NMR}\left(75 \mathrm{MHz}, \mathrm{C}_{6} \mathrm{D}_{6}, 25^{\circ} \mathrm{C}\right) \delta: 170.11,169.74(\mathrm{C}=\mathrm{O}), 169.33,169.06(\mathrm{CH}=\mathrm{N}), 161.09,160.51$ (Ar-O), 140.52, 139.45, 139.35, 138.96, 132.55, 130.98, 129.99, 129.46, 121.61, 121.27 (Ar), 63.21, $59.97\left(\mathrm{CH}_{2}\right), 51.19$, 51.05 (q- $-\mathrm{Bu}), 39.80,39.23\left(\mathrm{CH}_{2}\right), 34.96,34.79,34.13(2 \times)(\mathrm{q}-\mathrm{Bu}), 31.52,31.39,29.72,29.46,28.66,28.49$ (tBu) ppm; IR (ATR, $\left.\mathrm{cm}^{-1}\right) \tilde{v}: 3272(\mathrm{w}, \mathrm{NH}), 2958(\mathrm{~m}, \mathrm{C}-\mathrm{H}), 1666(\mathrm{~m}, \mathrm{C}=\mathrm{O}), 1611(\mathrm{C}=\mathrm{N}, \mathrm{s}), 1556(\mathrm{~m})$,

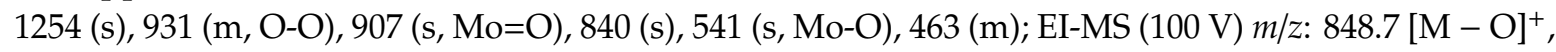
832.7 [M - $\left.\mathrm{O}_{2}\right]^{+}$; Anal. Calcd. for $\mathrm{C}_{44} \mathrm{H}_{70} \mathrm{MoN}_{4} \mathrm{O}_{7}: \mathrm{C}, 61.24 ; \mathrm{H}, 8.18 ; \mathrm{N}, 6.49$. Found: $\mathrm{C}, 60.14 ; \mathrm{H}, 7.66$; $\mathrm{N}, 6.36 \%$.

\subsubsection{Synthesis of $\left[\mathrm{MoO}\left(\mathrm{O}_{2}\right)(\mathrm{L3})_{2}\right](\mathbf{1 1})$}

For the synthesis of 11, 3 equiv of $\mathrm{PMe}_{3}(49 \mu \mathrm{L}, 0.48 \mathrm{mmol})$ were added to a suspension of 1 equiv of 3 (140 mg, $0.16 \mathrm{mmol})$ in dry toluene $(5 \mathrm{~mL})$, containing $3 \AA$ molecular sieves, and the mixture subsequently stirred under an $\mathrm{O}_{2}$ atmosphere $(1.5 \mathrm{~atm})$ at $50{ }^{\circ} \mathrm{C}$ for $6 \mathrm{~h}$, whereupon the solution gradually turned red. Subsequently, all volatiles were removed in vacuo. The resulting dark residue was dissolved in a minimum amount of dry acetonitrile and recrystallized at $-35^{\circ} \mathrm{C}$ to afford $11 \cdot \mathrm{OPMe}_{3}$ as a red crystalline solid $(36 \%, 58 \mathrm{mg})$. Single crystals suitable for X-ray diffraction analysis were obtained from a saturated MeCN solution at $-35^{\circ} \mathrm{C}\left(\mathbf{1 1} \cdot \mathrm{OPMe}_{3}, \mathbf{1 1} \cdot 2 \mathrm{OPMe}_{3}\right) .{ }^{1} \mathrm{H}-\mathrm{NMR}(300 \mathrm{MHz}$, $\left.\mathrm{C}_{6} \mathrm{D}_{6}, 25^{\circ} \mathrm{C}\right) \delta: 9.29(\mathrm{bs}, 2 \mathrm{H}, \mathrm{NH}), 8.56(\mathrm{~s}, 1 \mathrm{H}, \mathrm{CH}=\mathrm{N}), 8.47(\mathrm{~s}, 1 \mathrm{H}, \mathrm{CH}=\mathrm{N}), 7.92-7.89(\mathrm{~m}, 4 \mathrm{H}, \mathrm{Ph}), 7.59$ (d, 1H, ArH), $7.43(\mathrm{~d}, 1 \mathrm{H}, \mathrm{ArH}), 7.11-7.07(\mathrm{~m}, 4 \mathrm{H}, \mathrm{Ph}), 7.03(\mathrm{~d}, 1 \mathrm{H}, \mathrm{ArH}), 6.99(\mathrm{~d}, 1 \mathrm{H}, \mathrm{ArH}), 6.90-6.79$ (m, 2H, Ph), 5.59-5.43 (m, 1H, CH $\left.\mathrm{CH}_{2}\right), 5.26-5.09\left(\mathrm{~m}, 1 \mathrm{H}, \mathrm{CH}_{2}\right), 4.60-4.40\left(\mathrm{~m}, 2 \mathrm{H}, \mathrm{CH}_{2}\right), 3.51-2.99(\mathrm{~m}, 4 \mathrm{H}$, $\left.\mathrm{CH}_{2}\right), 1.26(\mathrm{~s}, 9 \mathrm{H}, t \mathrm{Bu}), 1.17(\mathrm{~s}, 9 \mathrm{H}, t \mathrm{Bu}), 1.14(\mathrm{~s}, 9 \mathrm{H}, t \mathrm{Bu}), 1.09(\mathrm{~s}, 9 \mathrm{H}, t \mathrm{Bu}), 0.90\left(\mathrm{~d}, 9 \mathrm{H}, \mathrm{OPMe}_{3}\right) \mathrm{ppm}$; ${ }^{13} \mathrm{C}-\mathrm{NMR}\left(75 \mathrm{MHz}, \mathrm{C}_{6} \mathrm{D}_{6}, 25{ }^{\circ} \mathrm{C}\right) \delta: 170.10,169.50,169.35,169.13(\mathrm{C}=\mathrm{O}, \mathrm{CH}=\mathrm{N}), 161.74,160.14(\mathrm{Ar}-\mathrm{O})$, 140.44, 139.75, 139.73, 139.70, 139.52, 138.99, 132.66, 131.09, 129.60, $129.32(\mathrm{Ar}), 129.00(\mathrm{Ph}), 123.78(\mathrm{Ph})$, 121.95, 121.73 (Ar), 120.18 (Ph), 62.63, 58.65, 39.39, $38.89\left(\mathrm{CH}_{2}\right), 34.96,35.83,34.10(2 \times)(\mathrm{q}-\mathrm{tBu}), 31.44$, 31.33, 29.65, $29.48(t \mathrm{Bu}), 17.65\left(\mathrm{~d}, \mathrm{OPMe}_{3}\right) \mathrm{ppm} ;{ }^{31} \mathrm{P}\left\{{ }^{1} \mathrm{H}\right\}-\mathrm{NMR}\left(121 \mathrm{MHz}, \mathrm{C}_{6} \mathrm{D}_{6}, 25{ }^{\circ} \mathrm{C}\right): 36.19\left(\mathrm{OPMe}_{3}\right)$ ppm; IR (ATR, cm ${ }^{-1}$ ) v: 3325 (br m, NH), 2957(m, C-H), 1653 (m, C=O), 1612(C=N, s), 1536 (m), 1255 (s), 1170 (m), 937 (m, O-O), 904 (s, Mo=O), 836 (s), 809 (m), 535 (w, Mo-O), 463 (m); EI-MS (100 V) m/z: $848.7\left[\mathrm{M}+\mathrm{H}_{2} \mathrm{O}\right]^{+}$; Anal. Calcd. for $\mathrm{C}_{48} \mathrm{H}_{62} \mathrm{MoN}_{4} \mathrm{O}_{7} \cdot \mathrm{OPMe}_{3} \cdot \mathrm{H}_{2} \mathrm{O}: \mathrm{C}, 60.47 ; \mathrm{H}, 7.26 ; \mathrm{N}, 5.54$. Found: $\mathrm{C}$, $59.77 ; \mathrm{H}, 6.41 ; \mathrm{N}, 5.31 \%$.

\section{Conclusions}

The reported synthesis of iminophenolate ligands equipped with pendant amidopropyl functionalities (HL2 and HL3) allowed for the successful synthesis and isolation of mononuclear dioxidomolybdenum(VI) complexes $\left[\mathrm{MoO}_{2} \mathbf{L}_{2}\right]$ (2 and 3). The here presented ligand design was successful in terms of an undesired cyclization of the ligand moieties, as previously observed with shorter amide substituents. More precisely, this cyclization reaction was prevented by introducing an additional methylene group between the imine and the amide functionality of the ligands. 
The resulting complexes $\mathbf{2}$ and $\mathbf{3}$ together with complex $\mathbf{1}$ featuring $n$-butyl side chains were reduced with $\mathrm{PMe}_{3}$ and subsequently exposed to molecular oxygen allowing the isolation of oxido peroxido complexes of the structure $\left[\mathrm{MoO}\left(\mathrm{O}_{2}\right) \mathbf{L}_{2}\right](\mathbf{9}-\mathbf{1 1})$. Thus, all complexes are capable of activating dioxygen in the desired fashion. The isolation of the reduced molybdenum(IV) intermediate was successful for the $n$-butyl ligand system, $\left[\mathrm{MoO}\left(\mathrm{PMe}_{3}\right)(\mathbf{L 1})_{2}\right](4)$, while increased sensitivity of complexes 5 and $\mathbf{6}$ prevented their isolation in pure form. Instead, three polynuclear secondary products could be identified via single-crystal X-ray diffraction analysis.

Complexes 1-3 were found to be moderately active catalysts in the aerobic oxidation of $\mathrm{PMe}_{3}$ while cyclooctene and dimethyl sulfide were not oxidized. Although formation of a weak hydrogen bond to the peroxido moiety was observed, it has no beneficial influence on the reactivity. Nevertheless, the here presented investigation reveals that hydrogen bonds may preferentially be formed to the product $\mathrm{OPMe}_{3}$ rather than to the peroxido group thereby decreasing their expected beneficial effect. Therefore, systems that are more reactive will have to consider less flexible substituents leading to stronger hydrogen bonds directed towards the peroxido oxygen atoms.

Supplementary Materials: The supplementary materials are available online.

Author Contributions: Conceptualization, N.C.M.-Z.; synthetic experiments, N.Z., M.A.E. and A.D.; catalysis, J.A.S.; X-ray analysis, F.B.; writing-original draft preparation, N.Z.; writing-review and editing, M.A.E. and J.A.S.; supervision, N.C.M.-Z.

Funding: This research was funded by the Austrian Science Fund (FWF, grant number P26264).

Conflicts of Interest: The authors declare no conflict of interest.

\section{References}

1. Hille, R.; Hall, J.; Basu, P. The Mononuclear Molybdenum Enzymes. Chem. Rev. 2014, 114, 3963-4038. [CrossRef]

2. Heinze, K. Bioinspired functional analogs of the active site of molybdenum enzymes: Intermediates and mechanisms. Coord. Chem. Rev. 2015, 300, 121-141. [CrossRef]

3. Hille, R.; Mendel, R. Molybdenum in living systems. Coord. Chem. Rev. 2011, 255, 991-992. [CrossRef]

4. Hine, F.J.; Taylor, A.J.; Garner, C.D. Dithiolene complexes and the nature of molybdopterin. Coord. Chem. Rev. 2010, 254, 1570-1579. [CrossRef]

5. Basu, P.; Burgmayer, S.J.N. Pterin chemistry and its relationship to the molybdenum cofactor. Coord. Chem. Rev. 2011, 255, 1016-1038. [CrossRef] [PubMed]

6. Kühn, F.E.; Santos, A.M.; Abrantes, M. Mononuclear organomolybdenum(VI) dioxo complexes: synthesis, reactivity, and catalytic applications. Chem. Rev. 2006, 106, 2455-2475. [CrossRef]

7. Mösch-Zanetti, N.C.; Wurm, D.; Volpe, M.; Lyashenko, G.; Harum, B.N.; Belaj, F.; Baumgartner, J. Replacement of an Oxo by an Imido Group in Oxotransferase Model Compounds: Influence on the Oxygen Atom Transfer. Inorg. Chem. 2010, 49, 8914-8921. [CrossRef] [PubMed]

8. Volpe, M.; Mösch-Zanetti, N.C. Molybdenum(VI) Dioxo and Oxo-Imido Complexes of Fluorinated $\beta$-Ketiminato Ligands and Their Use in OAT Reactions. Inorg. Chem. 2012, 51, 1440-1449. [CrossRef]

9. Majumdar, A.; Sarkar, S. Bioinorganic chemistry of molybdenum and tungsten enzymes: A structural-functional modeling approach. Coord. Chem. Rev. 2011, 255, 1039-1054. [CrossRef]

10. Young, C.G. Biomimetic chemistry of molybdenum. In Biomimetic Oxidations Catalyzed by Transition Metal Complexes; Meunier, B., Ed.; World Scientific: Singapore, 2000; pp. 415-459.

11. Groysman, S.; Holm, R.H. Biomimetic Chemistry of Iron, Nickel, Molybdenum, and Tungsten in Sulfur-Ligated Protein Sites. Biochemistry 2009, 48, 2310-2320. [CrossRef]

12. Holm, R.H.; Solomon, E.I.; Majumdar, A.; Tenderholt, A. Comparative molecular chemistry of molybdenum and tungsten and its relation to hydroxylase and oxotransferase enzymes. Coord. Chem. Rev. 2011, 255, 993-1015. [CrossRef]

13. Hauser, S.A.; Cokoja, M.; Kühn, F.E. Epoxidation of olefins with homogeneous catalysts-Quo vadis? Catal. Sci. Technol. 2013, 3, 552-561. [CrossRef] 
14. Lyashenko, G.; Saischek, G.; Judmaier, M.E.; Volpe, M.; Baumgartner, J.; Belaj, F.; Jancik, V.; Herbst-Irmer, R.; Mösch-Zanetti, N.C. Oxo-molybdenum and oxo-tungsten complexes of Schiff bases relevant to molybdoenzymes. Dalton Trans. 2009, 5655-5665. [CrossRef] [PubMed]

15. Judmaier, M.E.; Sala, C.H.; Belaj, F.; Volpe, M.; Mösch-Zanetti, N.C. Dimeric $\mu$-oxo bridged molybdenum(VI) dioxo complexes as catalysts in the epoxidation of internal and terminal alkenes. New J. Chem. 2013, 37, 2139. [CrossRef]

16. Judmaier, M.E.; Holzer, C.; Volpe, M.; Mösch-Zanetti, N.C. Molybdenum(VI) Dioxo Complexes Employing Schiff Base Ligands with an Intramolecular Donor for Highly Selective Olefin Epoxidation. Inorg. Chem. 2012, 51, 9956-9966. [CrossRef] [PubMed]

17. Schachner, J.A.; Traar, P.; Sala, C.H.; Melcher, M.; Harum, B.N.; Sax, A.F.; Volpe, M.; Belaj, F.; Mösch-Zanetti, N.C. Dioxomolybdenum(VI) Complexes with Pyrazole Based Aryloxide Ligands: Synthesis, Characterization and Application in Epoxidation of Olefins. Inorg. Chem. 2012, 51, 7642-7649. [CrossRef] [PubMed]

18. Zwettler, N.; Schachner, J.A.; Belaj, F.; Mösch-Zanetti, N.C. Hydrogen bond donor functionalized dioxido-molybdenum(VI) complexes as robust and highly efficient precatalysts for alkene epoxidation. Mol. Catal. 2017, 443, 209-219. [CrossRef]

19. Dupé, A.; Hossain, M.K.; Schachner, J.A.; Belaj, F.; Lehtonen, A.; Nordlander, E.; Mösch-Zanetti, N.C. Dioxomolybdenum(VI) and -Tungsten(VI) Complexes with Multidentate Aminobisphenol Ligands as Catalysts for Olefin Epoxidation. Eur. J. Inorg. Chem. 2015, 3572-3579. [CrossRef]

20. Gómez, M.; Jansat, S.; Muller, G.; Noguera, G.; Teruel, H.; Moliner, V.; Cerrada, E.; Hursthouse, M.B. First Dioxomolybdenum(VI) Complexes Containing Chiral Oxazoline Ligands: Synthesis, Characterization and Catalytic Activity. Eur. J. Inorg. Chem. 2001, 1071-1076. [CrossRef]

21. Bagherzadeh, M.; Tahsini, L.; Latifi, R.; Woo, L.K. cis-Dioxo-molybdenum(VI)-oxazoline complex catalyzed epoxidation of olefins by tert-butyl hydrogen peroxide. Inorg. Chim. Acta 2009, 362, 3698-3702. [CrossRef]

22. Bäckvall, J.-E. Modern Oxidation Methods; Wiley-VCH Verlag GmbH \& Co KGaA: Weinheim, Germany, 2010.

23. MacBeth, C.E.; Golombek, A.P.; Young, V.G., Jr.; Yang, C.; Kuczera, K.; Hendrich, K.; Borovik, A.S. O2 Activation by Nonheme Iron Complexes: A Monomeric Fe(III)-Oxo Complex Derived From $\mathrm{O}_{2}$. Science 2000, 289, 938-941. [CrossRef] [PubMed]

24. Shook, R.L.; Peterson, S.M.; Greaves, J.; Moore, C.; Rheingold, A.L.; Borovik, A.S. Catalytic reduction of dioxygen to water with a monomeric manganese complex at room temperature. J. Am. Chem. Soc. 2011, 133, 5810-5817. [CrossRef] [PubMed]

25. Nam, W. Synthetic Mononuclear Nonheme Iron-Oxygen Intermediates. Acc. Chem. Res. 2015, 48, $2415-2423$. [CrossRef] [PubMed]

26. Ray, K.; Pfaff, F.F.; Wang, B.; Nam, W. Status of Reactive Non-Heme Metal-Oxygen Intermediates in Chemical and Enzymatic Reactions. J. Am. Chem. Soc. 2014, 136, 13942-13958. [CrossRef]

27. Arzoumanian, H.; Petrignani, J.F.; Pierrot, M.; Ridouane, F.; Sanchez, J. Preparation of an oxoperoxocyanomolybdate(VI) complex by dioxygen oxidation of an oxocyanomolybdate(IV) anion. Structure and reactivity toward phosphines and olefins. Inorg. Chem. 1988, 27, 3377-3381. [CrossRef]

28. Tachibana, J.; Imamura, T.; Sasaki, Y. Synthesis and characterization of a novel dioxygen complex of molybdenum porphyrin. J. Chem. Soc. Chem. Commun. 1993, 1436-1438. [CrossRef]

29. Minato, M.; Zhou, D.-Y.; Sumiura, K.-I.; Oshima, Y.; Mine, S.; Ito, T.; Kakeya, M.; Hoshino, K.; Asaeda, T.; Nakada, T.; et al. Reactivity Patterns of $\mathrm{O}_{2}, \mathrm{CO}_{2}$, Carboxylic Acids, and Triflic Acid with Molybdenum Silyl Hydrido Complexes Bearing Polydentate Phosphinoalkyl-Silyl Ligands: Pronounced Effects of Silyl Ligands on Reactions. Organometallics 2012, 31, 4941-4949. [CrossRef]

30. Suzuki, M. Ligand effects on dioxygen activation by copper and nickel complexes: Reactivity and intermediates. Acc. Chem. Res. 2007, 40, 609-617. [CrossRef]

31. Duan, P.-C.; Manz, D.-H.; Dechert, S.; Demeshko, S.; Meyer, F. Reductive $\mathrm{O}_{2}$ Binding at a Dihydride Complex Leading to Redox Interconvertible $\mu$-1,2-Peroxo and $\mu$-1,2-Superoxo Dinickel(II) Intermediates. J. Am. Chem. Soc. 2018. [CrossRef]

32. DeRosha, D.E.; Mercado, B.Q.; Lukat-Rodgers, G.; Rodgers, K.R.; Holland, P.L. Enhancement of C-H Oxidizing Ability in $\mathrm{Co}_{2} \mathrm{O}_{2}$ Complexes through an Isolated Heterobimetallic Oxo Intermediate. Angew. Chem. Int. Ed. 2017, 56, 3211-3215. [CrossRef] 
33. Lyashenko, G.; Saischek, G.; Pal, A.; Herbst-Irmer, R.; Mösch-Zanetti, N.C. Molecular oxygen activation by a molybdenum(IV) monooxo bis(b-ketiminato) complex. Chem. Commun. 2007, 701-703. [CrossRef]

34. Dupé, A.; Judmaier, M.E.; Belaj, F.; Zangger, K.; Mösch-Zanetti, N.C. Activation of molecular oxygen by a molybdenum complex for catalytic oxidation. Dalton Trans. 2015, 44, 20514-20522. [CrossRef]

35. Zwettler, N.; Grover, N.; Belaj, F.; Kirchner, K.; Mösch-Zanetti, N.C. Activation of Molecular Oxygen by a Molybdenum(IV) Imido Compound. Inorg. Chem. 2017, 56, 10147-10150. [CrossRef]

36. Zwettler, N.; Judmaier, M.E.; Strohmeier, L.; Belaj, F.; Mösch-Zanetti, N.C. Oxygen activation and catalytic aerobic oxidation by $\mathrm{Mo}(\mathrm{IV}) /(\mathrm{VI})$ complexes with functionalized iminophenolate ligands. Dalton Trans. 2016, 45, 14549-14560. [CrossRef]

37. Zwettler, N.; Walg, S.; Belaj, F.; Mösch-Zanetti, N.C. Heterolytic Si-H bond cleavage at a molybdenum oxido based Lewis pair. Chem. Eur. J. 2018, 24, 7149-7160. [CrossRef] [PubMed]

38. Taguchi, T.; Gupta, R.; Lassalle-Kaiser, B.; Boyce, D.W.; Yachandra, V.K.; Tolman, W.B.; Yano, J.; Hendrich, M.P.; Borovik, A.S. Preparation and properties of a monomeric high-spin $\mathrm{Mn}(\mathrm{V})$-oxo complex. J. Am. Chem. Soc. 2012, 134, 1996-1999. [CrossRef] [PubMed]

39. Cook, S.A.; Borovik, A.S. Molecular Designs for Controlling the Local Environments around Metal Ions. Acc. Chem. Res. 2015, 48, 2407-2414. [CrossRef]

40. Cook, S.A.; Hill, E.A.; Borovik, A.S. Lessons from Nature: A Bio-Inspired Approach to Molecular Design. Biochemistry 2015, 54, 4167-4180. [CrossRef]

41. Bhattacharya, P.; Prokopchuk, D.E.; Mock, M.T. Exploring the role of pendant amines in transition metal complexes for the reduction of $\mathrm{N}_{2}$ to hydrazine and ammonia. Coord. Chem. Rev. 2017, 334, 67-83. [CrossRef]

42. Baba, K.; Okamura, T.-A.; Suzuki, C.; Yamamoto, H.; Yamamoto, T.; Ohama, M.; Ueyama, N. O-Atom-Transfer

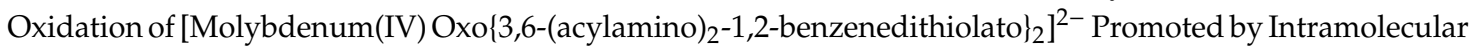
$\mathrm{NH}$...S Hydrogen Bonds. Inorg. Chem. 2006, 45, 894-901. [CrossRef]

43. Ueyama, N.; Okamura, T.; Nakamura, A. Structure and properties of molybdenum(IV,V) arenethiolates with a neighboring amide group. Significant contribution of NH.cntdot.cntdot.cntdot.S hydrogen bond to the positive shift of redox potential of $\mathrm{Mo}(\mathrm{V}) / \mathrm{Mo}(\mathrm{IV})$. J. Am. Chem. Soc. 1992, 114, 8129-8137. [CrossRef]

44. Zwettler, N.; Dupé, A.; Schachner, J.A.; Belaj, F.; Mösch-Zanetti, N.C. Templated C-C and C-N Bond Formation Facilitated by a Molybdenum(VI) Metal Center. Inorg. Chem. 2015, 54, 11969-11976. [CrossRef]

45. Traar, P.; Schachner, J.A.; Steiner, L.; Sachse, A.; Volpe, M.; Mösch-Zanetti, N.C. Oxorhenium(V) complexes with pyrazole based aryloxide ligands and application in olefin epoxidation. Inorg. Chem. 2011, 50, 1983-1990. [CrossRef] [PubMed]

46. Safaei, E.; Kabir, M.M.; Wojtczak, A.; Jagličić, Z.; Kozakiewicz, A.; Lee, Y.-I. Synthesis, crystal structure, magnetic and redox properties of copper(II) complexes of $N$-alkyl(aryl) tBu-salicylaldimines. Inorg. Chim. Acta 2011, 366, 275-282. [CrossRef]

47. Nahrwold, M.; Stoncius, A.; Penner, A.; Neumann, B.; Stammler, H.-G.; Sewald, N. 2-Phenyl-tetrahydropyrimidine-4 $(1 H)$-ones-cyclic benzaldehyde aminals as precursors for functionalised beta-amino acids. Beilstein J. Org. Chem. 2009, 5, 43. [CrossRef] [PubMed]

48. Gehrke, H.; Veal, J. Acetylacetonate complexes of molybdenum(V) and molybdenum(VI). I. Inorg. Chim. Acta 1969, 3, 623-627. [CrossRef]

49. Robin, T.; Montilla, F.; Galindo, A.; Ruiz, C.; Hartmann, J. Synthesis and characterization of dioxocomplexes of molybdenum with $\left(\eta-\mathrm{C}_{5} \mathrm{H}_{5}\right) \mathrm{Co}\left\{\mathrm{P}(\mathrm{O})(\mathrm{OEt})_{2}\right\}_{3}, \mathrm{C}_{5} \mathrm{H}_{4}\left(\mathrm{SiMe}_{3}\right)$ and 1,3- $\mathrm{C}_{5} \mathrm{H}_{3}\left(\mathrm{SiMe}_{3}\right)_{2}$ ligands. X-ray crystal structure of $\left[\left(\eta-\mathrm{C}_{5} \mathrm{H}_{5}\right) \mathrm{Co}\left\{\mathrm{P}(\mathrm{O})(\mathrm{OEt})_{2}\right\}_{3}\right] \mathrm{MoO}_{2} \mathrm{Cl}$. Polyhedron 1999, 18, 1485-1490. [CrossRef]

50. Sengar, R.S.; Miller, J.J.; Basu, P. Design, syntheses, and characterization of dioxo-molybdenum(VI) complexes with thiolate ligands: effects of intraligand NH ... S hydrogen bonding. Dalton Trans. 2008, 2569-2577. [CrossRef]

51. Kato, M.; Okamura, T.-A.; Yamamoto, H.; Ueyama, N. Effects of the intramolecular NH ... S hydrogen bond in mononuclear platinum(II) and palladium(II) complexes with 2,2'-bipyridine and benzenethiol derivatives. Inorg. Chem. 2005, 44, 1966-1972. [CrossRef]

52. Kato, M.; Kojima, K.; Okamura, T.-A.; Yamamoto, H.; Yamamura, T.; Ueyama, N. Relation between intramolecular $\mathrm{NH}$... S hydrogen bonds and coordination number in mercury(II) complexes with carbamoylbenzenethiol derivatives. Inorg. Chem. 2005, 44, 4037-4044. [CrossRef] [PubMed] 
53. Okamura, T.-A.; Iwamura, T.; Yamamoto, H.; Ueyama, N. Synthesis and molecular structures of $\mathrm{S}-2-\mathrm{FcNHCOC}_{6} \mathrm{H}_{4} \mathrm{SH}$ and [MIII(OEP)(S-2-FcNHCOC $\left.\left.6 \mathrm{H}_{4}\right)\right](\mathrm{Fc}=$ ferrocenyl, $\mathrm{M}=\mathrm{Fe}, \mathrm{Ga})$ : Electrochemical contributions of intramolecular $\mathrm{SH}$.. OC and $\mathrm{NH}$...S hydrogen bonds. J. Organomet. Chem. 2007, 692, 248-256. [CrossRef]

54. Choujaa, H.; Johnson, A.L.; Kociok-Köhn, G.; Molloy, K.C. The synthesis of W-O-W $\mu$-oxo clusters by hydrolysis of tungsten aminoalkoxides and their structural characterisation. Dalton Trans. 2012, 41, 11393-11401. [CrossRef]

55. Ziegler, J.E.; Du, G.; Fanwick, P.E.; Abu-Omar, M.M. An efficient method for the preparation of oxo molybdenum salalen complexes and their unusual use as hydrosilylation catalysts. Inorg. Chem. 2009, 48, 11290-11296. [CrossRef]

56. Leppin, J.; Förster, C.; Heinze, K. Molybdenum complex with bulky chelates as a functional model for molybdenum oxidases. Inorg. Chem. 2014, 53, 12416-12427. [CrossRef] [PubMed]

57. Ito, T.; Ide, R.; Kosaka, K.; Hasegawa, S.; Mikurube, K.; Taira, M.; Naruke, H.; Koguchi, S. Polyoxomolybdate-Surfactant Layered Crystals Derived from Long-tailed Alkylamine and Ionic Liquid. Chem. Lett. 2013, 42, 1400-1402. [CrossRef]

58. Mayer, J.M. Metal-oxygen multiple bond lengths: A statistical study. Inorg. Chem. 1988, 27, 3899-3903. [CrossRef]

59. Bingham, A.L.; Drake, J.E.; Hursthouse, M.B.; Light, M.E.; Kumar, R.; Ratnani, R. Synthesis, spectroscopic characterization and structural studies of bromodioxodimethylsulfoxide $\left(N, N^{\prime}\right.$-dialkyldithiocarbamates and $\mathrm{O}$-alkyl dithiocarbonate)molybdenum(VI) complexes: Crystal structures of $\mathrm{MoO}_{2} \mathrm{Br}_{2}\left(\mathrm{OSMe}_{2}\right)_{2}$ and $\mathrm{MoO}_{2} \mathrm{Br}_{2}\left(\mathrm{Cl}_{2} \mathrm{H}_{8} \mathrm{~N}_{2}\right) \bullet \mathrm{CH}_{2} \mathrm{Cl}_{2}$. Polyhedron 2006, 25, 3238-3244. [CrossRef]

60. Sheldrick, G.M. A short history of SHELX. Acta Crystallogr. A Found. Crystallogr. 2008, 64, 112-122. [CrossRef]

61. Sheldrick, G.M. Crystal structure refinement with SHELXL. Acta Crystallogr. C 2015, 71, 3-8. [CrossRef]

62. Göblyös, A.; Lázár, L.; Fülöp, F. Ring-chain tautomerism of 2-aryl-substituted-hexahydropyrimidines and tetrahydroquinazolines. Tetrahedron 2002, 58, 1011-1016. [CrossRef]

Sample Availability: Not available.

(C) 2019 by the authors. Licensee MDPI, Basel, Switzerland. This article is an open access article distributed under the terms and conditions of the Creative Commons Attribution (CC BY) license (http://creativecommons.org/licenses/by/4.0/). 